Growth performance, body composition, and digestive functionality of Senegalese sole (Solea senegalensis Kaup, 1858) juveniles fed diets including microalgae freeze-dried biomass

A. J. Vizcaíno, A. Rodiles, G. López, M. I. Sáez, M. Herrera, I. Hachero, T. F. Martínez, M. C. Cerón-García \& F. Javier Alarcón

Fish Physiology and Biochemistry

ISSN 0920-1742

Volume 44

Number 2

Fish Physiol Biochem (2018) 44:661-677 DOI 10.1007/s10695-018-0462-8

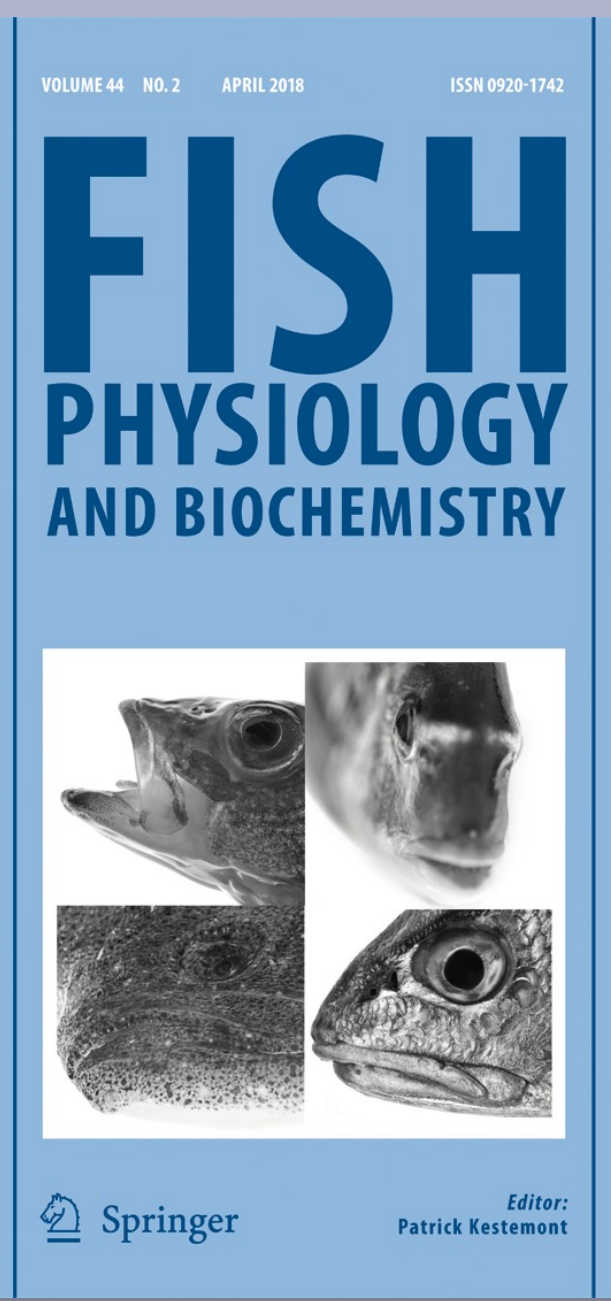


Your article is protected by copyright and all rights are held exclusively by Springer Science+Business Media B.V., part of Springer Nature. This e-offprint is for personal use only and shall not be self-archived in electronic repositories. If you wish to self-archive your article, please use the accepted manuscript version for posting on your own website. You may further deposit the accepted manuscript version in any repository, provided it is only made publicly available 12 months after official publication or later and provided acknowledgement is given to the original source of publication and a link is inserted to the published article on Springer's website. The link must be accompanied by the following text: "The final publication is available at link.springer.com". 


\title{
Growth performance, body composition, and digestive functionality of Senegalese sole (Solea senegalensis Kaup, 1858) juveniles fed diets including microalgae freeze-dried biomass
}

\author{
A. J. Vizcaíno • A. Rodiles • G. López • M. I. Sáez • \\ M. Herrera • I. Hachero • T. F. Martínez • \\ M. C. Cerón-García • F. Javier Alarcón iD \\ Received:27November2017/Accepted:3January2018/Publishedonline:21January2018 \\ (C) Springer Science+Business Media B.V., part of Springer Nature 2018
}

\begin{abstract}
Senegalese sole is one of the most promising fish species cultivated in the Southern European countries. This study was aimed at assessing the effects of microalgae biomass added to diets for Senegalese sole juveniles on fish growing and condition status. Three isoproteic (52\%) and isolipidic (10\%) were formulated containing 15\% Tisochrysis lutea (TISO), Nannochloropsis gaditana (NAN), or Scenedesmus almeriensis (SCE) biomass, respectively. An experimental microalgae-free diet (CT) and a commercial diet (COM) were used as controls. Fish were fed at $3 \%$ of their body weight for 85 days. Final
\end{abstract}

\footnotetext{
A. J. Vizcaíno · G. López · M. I. Sáez · T. F. Martínez •

F. J. Alarcón $(\bowtie)$

Departamento de Biología y Geología, Escuela Superior de Ingeniería, Universidad de Almería, La Cañada de San Urbano, 04120 Almería, Spain

e-mail: falarcon@ual.es

A. Rodiles

School of Biological Sciences, Plymouth University, Plymouth, UK
}

M. Herrera

IFAPA Centro Agua del Pino, Huelva, Spain

I. Hachero

Centro Oceanográfico de Vigo, Instituto Español de Oceanografía, 36390 Vigo, Spain

M. C. Cerón-García

Departamento de Ingeniería Química, CITE II-A, Universidad de Almería, La Cañada de San Urbano, 04120 Almería, Spain body weight of fish fed microalgae-supplemented diets did not differ from group fed CT diet. Fish-fed CT, TISO, NAN, and SCE showed higher growth performance and nutrient utilization figures than specimen-fed COM diet. The highest carcass lipid content was found in COM group $\left(141 \mathrm{~g} \mathrm{~kg}^{-1}\right)$, and no differences were observed in body protein content. Ash was significantly higher in TISO, NAN, and SCE groups compared to fish-fed CT. Muscle EPA and DHA contents were not modified owing to the different dietary treatments. The $\mathrm{n} 3 / \mathrm{n} 6$ and EPA/DHA ratios in muscle were similar in all the experimental groups. The quantification of digestive proteolytic activities did not differ among experimental groups, although differences in the protease pattern in digestive extracts by zymography were revealed in those fish fed on COM diet. Both $\alpha$-amylase activity in the intestinal lumen and leucine aminopeptidase in the intestinal tissue were significantly lower in COM fish. Specimens fed on SCE diet showed a higher leucine aminopeptidase activity associated to the intestinal tissue compared to NAN-fed fish ( 0.40 and $0.25 \mathrm{U} \mathrm{g}$ tissue $^{-1}$, respectively). The ultrastructural study revealed that the dietary inclusion of algal biomass, especially $T$. lutea and $N$. gaditana, had a positive impact on the absorptive capacity of the intestinal mucosa. The highest values for the parameters microvilli length and microvilli absorption surface were observed in fish fed on NAN diet $(1.99 \mu \mathrm{m}$ and $45.93 \mu^{2}$, respectively). Even though further studies aimed at optimizing commercial formulas 
for Senegalese sole are required prior to any largescale practical utilization, the results obtained clearly suggest the potential of microalgae as dietary ingredients for this fish species.

Keywords Aquafeed Fish nutrition - Tisochrysis lutea . Microalgae $\cdot$ Nannochloropsis gaditana $\cdot$ Scenedesmus almeriensis $\cdot$ Senegalese sole

\section{Introduction}

In recent years, aquaculture production in the Southern European countries has been just focused on a few marine species, especially gilthead sea bream (Sparus aurata) and European sea bass (Dicentrarchus labrax). Nevertheless, increased production of these two species has led to market saturation and price reduction (Morais et al. 2004). It is likely that any further thriving in the competitiveness of the European aquaculture industry will be more closely related to the capacity to diversify the market offer, than to increase productivity. Given its high commercial value, Senegalese sole (Solea senegalensis, Kaup 1858) has already gained the status of being one of the most interesting and promising fish species for cultivation (Dinis et al. 1999; Imsland et al. 2003).

The protein requirement of Senegalese sole has been estimated at $50 \%$ of the diet (Rema et al. 2008; Rubio et al. 2009). Traditionally, fishmeal has been the main protein ingredient in aquafeeds, owing to its high protein digestibility and excellent composition of essential aminoacids and fatty acids (Olsen and Hasan 2012). Some alternative protein ingredients have been successfully used to partially replace fishmeal in aquafeeds. Thereby, plant-derived ingredients such as soybean meal, soybean protein concentrate, rapeseed meal, corn gluten meal, and wheat gluten fulfill many of the nutritional characteristics required to replace, at least partially, fishmeal. Indeed, all of them have been widely used for partial or total fishmeal substitution in Senegalese sole diets (Silva et al. 2010; Cabral et al. 2011, 2013; Moreira et al. 2014; Rodiles et al. 2015), as well as in other flatfish species such as turbot, Psetta maxima (Fournier et al. 2004), Japanese flounder, Paralichthys olivaceus (Pham et al. 2007), halibut, Hippoglossus hippoglossus (Murray et al. 2010) or Egyptian sole, Solea aegyptiaca (Gatta et al. 2011).
Thus, high or total fishmeal replacement by plant protein can decrease fish growth (Lin and Luo 2011; Cabral et al. 2013) and even adversely affect the activity of digestive enzymes (Santigosa et al. 2008) as well as the integrity of the gastrointestinal epithelium (Merrifield et al. 2009). Consequently, the need to find alternative protein ingredients without any detrimental impact on fish physiology remains a key priority in aquaculture.

Several microalgae might well represent a promising alternative in this regard, either as ingredients aimed at replacing fishmeal or even as bioactive feed additives (Lupatsch 2009). The high protein content (30-55\% dry weight basis) makes microalgae biomass particularly interesting in fish nutrition. In addition, microalgae show unique fatty acid profile, and they are also a valuable source of essential vitamins and natural pigments (Spolaore et al. 2006). The potential of microalgae, such as Isochrysis sp., Nannochloropsis $s p$., and Scenedesmus almeriensis, as aquafeed ingredient has been assessed in several experiments (Walker and Berlinsky 2011; Tibaldi et al. 2015; Vizcaíno et al. 2014, 2016). Most studies feeding microalgae biomass to marine fish have reported improved growth, nutrient retention, and gastrointestinal morphology (Güroy et al. 2007; Hussein et al. 2013; Vizcaíno et al. 2014, 2016). Nevertheless, adverse effects on fish growth have also been reported (Walker and Berlinsky 2011). Apparently, the physiological effects of microalgae are dosedependent and species-specific, and thus, no general rule can be set out. Consequently, there is the need to conduct research for each specific case. In this regard, as far as we know, no studies assessing the effect of microalgae as dietary ingredients in feeds for Senegalese sole juveniles have been published to date.

The aim of the present research was to assess the effects of the dietary inclusion of Tisochrysis lutea (TISO), Nannochloropsis gaditana (NAN), and Scenedesmus almeriensis (SCE) biomass on growth performance, proximate composition, and digestive functionality of $S$. senegalensis juveniles.

\section{Materials and methods}

Microalgae biomass

Microalgae were provided by Estación Experimental "Las Palmerillas" (Fundación Cajamar, Almería, 
Spain). The cells were produced in a semiindustrialsized (3000 L) outdoor tubular photobioreactor (PBR) in continuous mode. This facility is designed to operate with seawater or fresh water in a closed circuit, with recirculation of the culture medium. Agricultural fertilizers were used instead of pure chemicals at a calcium nitrate concentration of $11 \mathrm{mM}$, according to the commercial medium Algal (Bionova, Santiago de Compostela, Spain). The inorganic compounds were added to artificial seawater using $30 \mathrm{~g} \mathrm{~L}^{-1} \mathrm{NaCl}$ (TorreSal, Unión Salinera de España). The PBR used was a closed, vertical, and tubular system made up by a 400-m length tube with a diameter of $0.09 \mathrm{~m}$ in a twoplane loop configuration (Torzillo et al. 1986) for degassing and heat exchanging. The tube diameter was optimized to maximize the volume of culture whilst maximizing the interception of solar radiation in order to optimize microalgae photosynthesis. Values of $\mathrm{pH}$, temperature, and dissolved oxygen were continuously monitored at the end of the loop by using specific probes (Crison Instruments, Spain). Pure $\mathrm{CO}_{2}$ was injected ondemand with the aim of maintaining $\mathrm{pH}$ 7.8. The system was programmed to keep temperature within the range required for optimal growth of each microalgae strain (T. lutea $23-25{ }^{\circ} \mathrm{C}, N$. gaditana $25-27{ }^{\circ} \mathrm{C}$, and S. almeriensis $28-30{ }^{\circ} \mathrm{C}$ ). The culture was kept under continuous circulation by using a centrifugal pump at $0.9 \mathrm{~m} \mathrm{~s}^{-1}$. The PBR was bubbled at a constant airflow rate of $200 \mathrm{~L} \mathrm{~min}^{-1}$. The biomass was harvested daily by centrifugation (RINA centrifuge, Riera Nadeu SA, Spain), frozen at $-18^{\circ} \mathrm{C}$, lyophilized, and finally milled to obtain a homogenized powder $(<100 \mu \mathrm{m})$ that was stored in the dark at $-20^{\circ} \mathrm{C}$ until further preparation of the experimental diets.

\section{Experimental diets}

Four isonitrogenous (52\% on dry weight basis) experimental diets were manufactured at the $\mathrm{CEIA}_{3}$ Universidad de Almería facilities (Service of Experimental Diets, http://www.ual.es/stecnicos_spe). Three experimental diets were formulated to include $15 \%$ $(w / w)$ freeze-dried T. lutea (TISO), N. gaditana (NAN), or $S$. almeriensis (SCE) biomass. A microalgae-free diet was used as control (CT). The formulation and chemical composition of the experimental diets are shown in Tables 1 and 2. Feed ingredients were finely ground and mixed in a vertical helix ribbon mixer (Sammic BM-10, 10-L capacity, Sammic,
Azpeitia, Spain) before fish oil and diluted choline chloride were added. All the ingredients were mixed together for $15 \mathrm{~min}$ and then water $\left(300 \mathrm{~mL} \mathrm{~kg}^{-1}\right)$ was added to the mixture to obtain a homogeneous dough. The dough was passed through a single screw laboratory extruder (Miltenz 51SP, JSConwell Ltd., New Zealand), to form 1-2 mm (diameter) and 2-3 mm (length) pellets. The extruder barrel consisted of four sections and the temperature profile in each section (from inlet to outlet) was $100,95,90$, and $85^{\circ} \mathrm{C}$, respectively. Finally, pellets were dried at room temperature for $24 \mathrm{~h}$ and kept in sealed plastic bags at $-20{ }^{\circ} \mathrm{C}$ until use. In addition, a flatfish commercial feed, COM $(55 \%$ crude protein and $15 \%$ crude lipid) was also used as a second microalgaefree control diet. The approximate ingredient composition $(\% w / w)$ of COM diet was fishmeal LT (37.040.0), CPSP (3.0-5.0), squid meal (3.0-5.0), soybean meal (16.0-20.0), corn gluten meal (12.0-18.0), wheat meal (10.0-18.0), wheat gluten (3.0-6.0), fish oil (12.0-14.0), choline chloride (0.10), mineral and vitamin mix (0.33), and betaine $(0.07)$.

\section{Fish and feeding trial}

Feeding trial was carried out at the "Agua de Pino" facilities (IFAPA, Huelva, Spain). After a 15-day acclimation period, 300 fish were selected (body weight $11.4 \pm 0.3 \mathrm{~g}$ ) and randomly distributed (20 fish per tank) in 15 polypropylene gray rectangular tanks $(77 \times 56 \times$ $22 \mathrm{~cm} ; 80 \mathrm{~L} ; 0.48 \mathrm{~L} \mathrm{~min}^{-1}$ flow rate). Experiments were conducted in triplicate ( 5 feeds $\times 3$ tanks each feed), and fish were fed the five different diets twice per day (9:00 and 17:00 h), 7 days per week at a rate of $3 \%$ of their body weight. Leftover feed particles were carefully collected by siphoning $60 \mathrm{~min}$ after the administration, then dried for $12 \mathrm{~h}$ at $110{ }^{\circ} \mathrm{C}$, and weighed (Barroso et al. 2013). The trial was carried out during 85 days from March to June in a flow-through filtered seawater system $(1 \mu \mathrm{m})$ sterilized with UV, under constant temperature $\left(19.0 \pm 1.1^{\circ} \mathrm{C}\right)$ and salinity $(35 \pm 1 \%$ ), with a $12 \mathrm{~L}: 12 \mathrm{D}$ photoperiod. Supplemental aeration was provided to maintain dissolved oxygen at $6.8 \pm 0.4 \mathrm{mg} \mathrm{L}^{-1}$. Ammonia $\left(<0.1 \mathrm{mg} \mathrm{L}^{-1}\right)$, nitrite $\left(<0.2 \mathrm{mg} \mathrm{L}^{-1}\right)$ and nitrate $\left(<50 \mathrm{mg} \mathrm{L}^{-1}\right)$ were determined once weekly at 9:00. All experimental procedures complied with the Guidelines of the European Union (Directive 2010/63/ UE) and the Spanish legislation (Real Decreto 52/2013) regarding the use of laboratory animals. 
Table 1 Ingredients and proximate composition of the experimental diets used in the feeding trial

\begin{tabular}{|c|c|c|c|c|}
\hline & $\mathrm{CT}$ & TISO & NAN & SCE \\
\hline \multicolumn{5}{|l|}{ Ingredients ( $\left.\mathrm{g} \mathrm{kg}^{-1} \mathrm{DM}\right)$} \\
\hline Fishmeal $^{1}$ & 661 & 585 & 568 & 565 \\
\hline Tisochrysis meal ${ }^{2}$ & & 150 & & \\
\hline Nannochloropsis meal ${ }^{3}$ & & & 150 & \\
\hline Scenedesmus meal $^{4}$ & & & & 150 \\
\hline Squid meal & 50 & 50 & 50 & 50 \\
\hline Fish protein hydrolysate, CPSP $90^{5}$ & 50 & 50 & 50 & 50 \\
\hline Soybean protein concentrate ${ }^{6}$ & 25 & 25 & 25 & 25 \\
\hline Fish oil & 60 & 37 & 30 & 58 \\
\hline Maltodextrin & 88 & 37 & 61 & 36 \\
\hline Vitamin and mineral premix ${ }^{7}$ & 28 & 28 & 28 & 28 \\
\hline Binder (sodium alginate) ${ }^{8}$ & 38 & 38 & 38 & 38 \\
\hline \multicolumn{5}{|l|}{ Proximate composition ( $\left.\mathrm{g} \mathrm{kg}^{-1} \mathrm{DM}\right)$} \\
\hline Crude protein & 529 & 517 & 526 & 533 \\
\hline Crude lipid & 105 & 90 & 99 & 101 \\
\hline Ash & 164 & 158 & 158 & 152 \\
\hline Crude fiber & 3 & 1 & 2 & 2 \\
\hline Moisture & 91 & 99 & 98 & 104 \\
\hline $\mathrm{NfE}^{9}$ & 201 & 235 & 217 & 213 \\
\hline
\end{tabular}

Dietary treatment codes are CT: control; TISO: $15 \%$ Tisochrysis meal inclusion (35.2\% crude protein, $21.5 \%$ crude lipid, $31.1 \%$ NfE, and $12.2 \%$ ash); NAN: $15 \%$ Nannochloropsis meal inclusion (43.1\% crude protein, $27.3 \%$ crude lipid, $22.2 \% \mathrm{NfE}$, and $7.4 \%$ ash); SCE: $15 \%$ Scenedesmus meal inclusion (44.6\% crude protein, $9.1 \%$ crude lipid, $36.2 \% \mathrm{NfE}$, and $10.1 \%$ ash)

${ }^{1} 69.4 \%$ crude protein, $12.3 \%$ crude lipid, Norsildemel (Bergen, Norway)

${ }^{2} 35 \%$ crude protein, $21 \%$ crude lipid

${ }^{3} 43 \%$ crude protein, $27 \%$ crude lipid

${ }^{4} 44 \%$ crude protein, $9 \%$ crude lipid

${ }^{5} 81 \%$ crude protein, $8.8 \%$ crude lipid, Sopropeche (France)

${ }^{6} 65 \%$ crude protein, $8 \%$ crude lipid, DSM (France)

${ }^{7}$ Mineral and vitamin premix according to Pereira and Oliva-Teles (2003)

${ }^{8}$ Sigma-Aldrich (Madrid, Spain)

${ }^{9} \mathrm{NfE}$ : Nitrogen free extract calculated as $100-(\%$ crude protein + $\%$ crude lipid $+\%$ ash $+\%$ crude fiber $)$

Fish sampling

Fish were individually weighed and measured every 2 weeks after 24-h fasting. At the end of the feeding trial, all fish were anesthetized and killed with an overdose of isoeugenol followed by decapitation. Then, fish were dissected, and the skinless carcasses were freeze- dried and stored at $-20{ }^{\circ} \mathrm{C}$ for further proximate composition analysis. Additionally, muscle and liver samples were freeze-dried for fatty acid analysis, and the intestine of three specimens from each tank was collected for examination by light and electron microscopy (TEM).

Growth performance, nutrient utilization, and somatic indices

Growth and nutrient utilization were estimated using several morphometric and biometric indices. Daily Gain $\left(\mathrm{DG}, \mathrm{mg}\right.$ day $\left.^{-1}\right)=(\mathrm{Wf} / \mathrm{Wi}) /$ day, where Wf and Wi were final and initial weight $(\mathrm{g})$; specific growth rate $(\mathrm{SGR}, \%)=(\mathrm{Ln}(\mathrm{Wf})-\mathrm{Ln}(\mathrm{Wi}) /$ days $) \times 100$; feed conversion ratio $(\mathrm{FCR})=$ total feed intake in dry basis (g) / weight gain $(\mathrm{g})$; protein efficiency ratio $(\mathrm{PER})=$ WG / total protein ingested $(\mathrm{g})$, where WG was the weight gain $(\mathrm{g})$. Biometric and somatic indices were calculated according to the following formulae: $\mathrm{K}$ factor $(\%)=$ fish weight $(\mathrm{g}) /$ fish length $\left.^{3}(\mathrm{~cm})\right) \times 100$; Viscerosomatic Index $(\mathrm{VI}, \%)=($ visceral weight $(\mathrm{g}) /$ whole body weight $(\mathrm{g})) \times 100$, and Hepatosomatic Index $($ HSI, \%) $=($ liver weight $(\mathrm{g}) /$ whole body weight (g) $) \times 100$.

Proximate composition and fatty acid profile

Chemical analysis of feeds and fish carcasses was carried out following the methods by AOAC (2000) for dry matter and ash, whereas crude protein $(\mathrm{N} \times 6.25)$ was determined by using elemental analysis $(\mathrm{C}: \mathrm{H}: \mathrm{N})$ with a Fisons EA 1108 analyzer (Fisons Instruments, Beverly, MA, USA). Total lipid content was analyzed according to Christie (1982). Fatty acid profile of feeds and tissue samples was determined by gas chromatography following the method of Rodríguez-Ruiz et al. (1998). This analysis was carried out with a gas chromatograph Hewlett Packard, 4890 Series II (Hewlett Packard Company, Avondale, PA) using modification of direct transesterification method described by Lepage and Roy (1984) that requires no prior separation of the lipid fraction.

Analysis of digestive enzyme activities

Intestine samples from each treatment were processed to obtain two types of crude extracts for the determination of enzyme activities. For each intestinal sample, tissue 
Table 2 Fatty acid composition (\% dry weight of relevant fatty acids) of microalgae and the diets

\begin{tabular}{|c|c|c|c|c|c|c|c|c|}
\hline & T. lutea & $N$. gaditana & S. almeriensis & $\mathrm{COM}$ & $\mathrm{CT}$ & TISO & NAN & SCE \\
\hline $14: 0$ & 15.5 & 7.80 & 0.99 & 5.40 & 3.84 & 5.26 & 4.41 & 3.76 \\
\hline $16: 0$ & 11.0 & 27.3 & 15.9 & 16.6 & 19.1 & 20.5 & 22.3 & 20.1 \\
\hline 18:0 & 0.59 & 0.45 & 0.35 & 3.11 & 4.73 & 4.41 & 4.61 & 4.87 \\
\hline $18: \ln 9$ & 11.1 & 3.96 & 5.19 & 8.31 & 8.96 & 9.37 & 9.26 & 11.2 \\
\hline $18: 2 \mathrm{n} 6$ & 4.65 & 3.85 & 6.32 & 5.90 & 9.77 & 9.35 & 9.96 & 8.98 \\
\hline $18: 3 n 3$ & 6.87 & & 27.9 & 1.22 & 1.57 & 1.53 & 1.59 & 3.25 \\
\hline $20: 4 n 6$, ARA & & 4.75 & & 0.89 & 1.35 & 1.52 & 2.08 & 1.21 \\
\hline $20: 5 n 3$, EPA & 1.28 & 23.5 & & 15.5 & 10.1 & 13.4 & 13.1 & 9.46 \\
\hline $\begin{array}{r}\text { 22:6n3, } \\
\text { DHA }\end{array}$ & 10.2 & & & 10.7 & 19.0 & 14.6 & 12.3 & 15.7 \\
\hline SFA & & & & 25.1 & 27.7 & 30.2 & 31.3 & 28.7 \\
\hline MUFA & & & & 21.6 & 19.0 & 21.0 & 26.0 & 20.8 \\
\hline HUFA & & & & 38.7 & 45.6 & 43.5 & 42.2 & 42.2 \\
\hline n3 & & & & 29.2 & 33.0 & 31.0 & 28.5 & 30.2 \\
\hline n6 & & & & 6.79 & 11.1 & 10.9 & 12.0 & 10.2 \\
\hline n9 & & & & 12.7 & 10.8 & 10.7 & 10.5 & 13.0 \\
\hline
\end{tabular}

and content were differentiated, and processed separately. Tissue and content of the same intestine sample were manually homogenized in distilled water at $4{ }^{\circ} \mathrm{C}$ to a final concentration of $0.5 \mathrm{~g} \mathrm{~mL}^{-1}$. Supernatants were obtained after centrifugation $\left(13,000 \mathrm{~g}, 12 \mathrm{~min}, 4{ }^{\circ} \mathrm{C}\right)$ and stored at $-20{ }^{\circ} \mathrm{C}$ for further enzymatic analysis. Total soluble protein in enzyme extracts was determined according to Bradford (1976), using bovine serum albumin as standard. Total alkaline protease activity in digestive extracts was spectrophotometrically measured according to Alarcón et al. (1998) using $5 \mathrm{~g} \mathrm{~L}^{-1}$ casein in $50 \mathrm{mM}$ Tris $\mathrm{HCl}(\mathrm{pH} \mathrm{9.0)}$ as substrate. One unit of total protease activity was defined as the amount of enzyme that released $1 \mu \mathrm{g}$ of tyrosine per min in the reaction mixture, considering an extinction coefficient for tyrosine of $0.008 \mathrm{\mu g}^{-1} \mathrm{~mL}^{-1} \mathrm{~cm}^{-1}$, measured at $280 \mathrm{~nm}$. Trypsin and chymotrypsin activities were determined by using $0.5 \mathrm{mM}$ BAPNA (N-a-benzoyl-DLarginine-4-nitroanilide) as substrate according to Erlanger et al. (1961), and $0.2 \mathrm{mM}$ SAPNA (Nsuccinyl-(Ala) ${ }_{2}$-Pro-Phe-P-nitroanilide) according to DelMar et al. (1979), respectively, in $50 \mathrm{mM}$ Tris- $\mathrm{HCl}$ buffer, $\mathrm{pH} 8.5$, containing $10 \mathrm{mM} \mathrm{CaCl} 2$. Alphaamylase activity was measured using 2-chloro-4nitrophenyl- $\alpha$-D-maltotriose as substrate (Amylase MR, Clonatest, \# KR10065). Leucine aminopeptidase and alkaline phosphatase activities were assayed using $2 \mathrm{mM}$ L-Leucine-p-nitroanilide in $100 \mathrm{mM}$ Tris- $\mathrm{HCl}$ buffer, $\mathrm{pH} 8.8$ (Pfleiderer 1970) and p-nitrophenyl phosphate in $1 \mathrm{M}$ diethanolamine buffer, $\mathrm{pH} 9.5$, containing $1 \mathrm{mM} \mathrm{MgCl} 2$ (Bergmeyer 1974) as substrates, respectively. For trypsin, chymotrypsin, and leucine aminopeptidase activities, one unit of enzyme activity (U) was defined as the amount of enzyme that released $1 \mu \mathrm{mol}$ of p-nitroanilide per min, using as extinction coefficient $8800 \mathrm{M} \mathrm{cm}^{-1}$, measured at $405 \mathrm{~nm}$. For alkaline phosphatase and $\alpha$-amylase, one unit of activity was defined as the amount of enzyme that releases $1 \mu \mathrm{g}$ of nitrophenyl per min considering a coefficient molar extinction of p-nitrophenol, 17,800 $\mathrm{M} \mathrm{cm}^{-1}$, measured at $405 \mathrm{~nm}$. All assays were performed in triplicate, and specific enzymatic activity was expressed as $\mathrm{U} g$ tissue ${ }^{-1}$.

In addition, digestive proteases were separated and visualized using substrate-SDS-PAGE electrophoresis gels. Intestinal extracts were mixed with SDS sample buffer $(1: 1)$ and SDS-PAGE was performed according to Laemmli (1970) using $11 \%$ polyacrylamide (100 V per gel, $45 \mathrm{~min}, 4{ }^{\circ} \mathrm{C}$ ). Zymograms revealing protease active bands were made using the method described by Alarcón et al. (1998).

Liver and intestine histological analysis

Liver and intestine samples were fixed for $24 \mathrm{~h}$ in phosphate-buffered formalin (4\% v/v, pH 7.2), dehydrated and embedded in paraffin according to 
standard histological techniques. Samples were cut in $5 \mu \mathrm{m}$ transversal sections and the slides were stained with hematoxylin-eosin (H\&E). The stained preparations were examined under Olympus ix51 light microscope (Olympus España, Barcelona, Spain) equipped with a digital camera CC12 (Olympus Soft Imaging Solutions GmdH, Muenster, Germany). The images were analyzed using specific software (UTHSCA ImageTool, University of Texas, Health Science Center, San Antonio, Texas, http://ddsdx. uthscsa.edu). Hepatocyte area and hepatocyte major axis were measured in liver samples, whereas the length of mucosal folds and total enterocyte height (10 independent measurements in proximal and distal intestine per animal) were determined in intestinal samples.

\section{Electron microscopy study}

Samples for transmission electron microscopy (TEM) were fixed for $4 \mathrm{~h}$ at $4{ }^{\circ} \mathrm{C}$ in $25 \mathrm{~g} \mathrm{~L}^{-1}$ glutaraldehyde and $40 \mathrm{~g} \mathrm{~L}^{-1}$ formaldehyde dissolved in phosphate buffer saline (PBS) $\mathrm{pH}$ 7.5. After fixation, samples were washed three times for $20 \mathrm{~min}$ with PBS. Next, a post-fixation with $20 \mathrm{~g} \mathrm{~L}^{-1}$ osmium tetroxide was done and tissues were dehydrated by consecutive immersions (20 min each) in gradient ethanol solutions ranging from $50 \%$ to $100 \%(v / v)$. Samples were embedded in a mixture 1:1 of ethanol $100 \%(v / v)$ and Epon resine for $2 \mathrm{~h}$ under continuous shaking and then, they were included in pure Epon resine for $24 \mathrm{~h}$, and polymerized at $60^{\circ} \mathrm{C}$. Finally, the ultrafine cuts were placed on a $700 \AA$ cooper mesh and stained with uranile acetate and lead citrate. The observation of the samples was performed with a transmission electron microscope Zeiss 10C at $100 \mathrm{Kv}$ (Carl Zeiss, Barcelona, Spain). TEM visualization fields were recorded ( $\times 16,000$ magnification), and digital images were analyzed using UTHSCA ImageTool software. At least 100 independent measurements of the anterior intestine per treatment were carried out. TEM micrographs were analyzed to measure microvilli length and microvilli diameter and the number of microvilli over $1 \mu \mathrm{m}^{2}$ surface (Hu et al. 2007). Taking into account the cylindrical shape of microvilli, data obtained from images were used to estimate the total absorption surface per microvilli according to Vizcaíno et al. (2014).
Statistical analysis

Results are expressed as mean \pm standard deviation. In order to test data normality and variance homogeneity, the Kolmogorov-Smirnov's test and Levene's F-test were used, respectively. Data with parametric distribution were analyzed using a one-way analysis of variance (ANOVA) and the significant differences between treatments $(p<0.05)$ were determined using Tukey's multiple comparison test. Data with nonparametric distribution were analyzed using Kruskal-Wallis test, and significant differences were determined using Box and Whisker Plots graphs. In addition, a comparison of means (Student's $t$ test) was carried out in order to determine possible differences in enzymatic activity between tissue and content of the same intestinal samples. All statistical analyses were performed using the Stagraphics Plus 4.0 (Rockville, MD, USA) software.

\section{Results}

Growth performance, nutrient utilization, and proximate composition

The fish readily accepted all diets. Mortality was $7 \%$ on average, and no differences could be attributable to dietary treatments. The growth of Senegalese sole fed on the experimental diets throughout the 85-day trial is shown in Fig. 1. At the end of the feeding period, fish fed on COM diet showed significantly lower final body weight than fish fed on CT, TISO, NAN, and SCE diets. The final body weight of fish fed microalgaesupplemented diets did not differ from group fed with CT diet. DG, SGR and nutrient utilization parameters (FCR, FER, and PER) of fish fed on COM significantly differed from the rest of experimental groups. K-factor and somatic indices (VI and HSI) did not change owing to dietary treatments (Table 3). The inclusion of microalgae did not modify body protein or lipid contents in Senegalese sole specimens. Fish fed on COM diet showed the highest carcass lipid content. Only ash was significantly higher $(p<0.05)$ in TISO, NAN, and SCE groups compared to specimens fed on CT diet (Table 4).

Fatty acid profile

Polyunsaturated fatty acids (PUFA) were the predominant lipids in hepatic tissue (33-40\%), followed by 
Fig. 1 Time course variation of body weight of fish fed the different diets. Asterisk denotes significant differences among dietary treatments

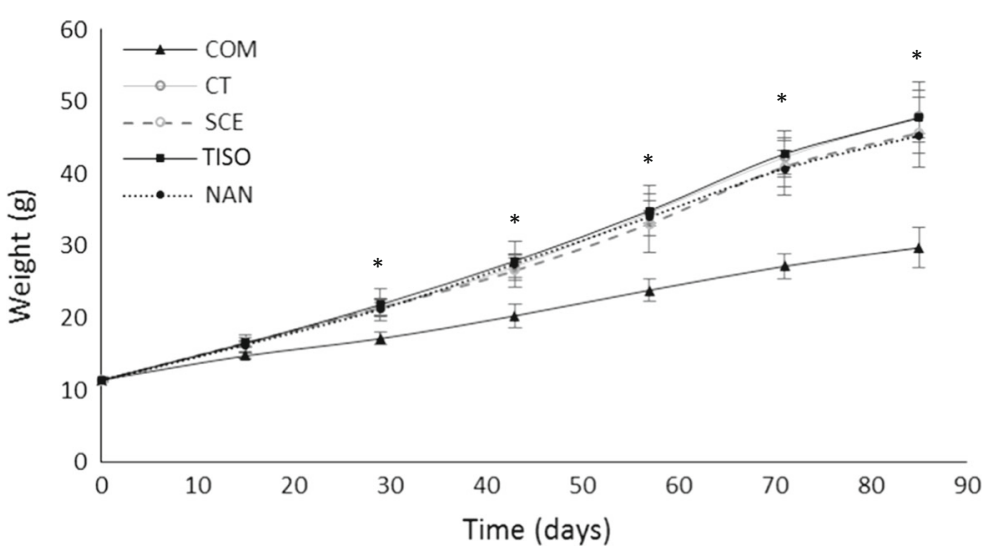

saturated fatty acids (SFA) (28-31\%), and monounsaturated fatty acids (MUFA) (23-27\%), regardless of dietary treatment $(p>0.05)$. Fish fed on COM diet showed non-significant higher SFA and MUFA values in the liver, as well as lower PUFA content among treatment groups (Table 5). PUFA was the predominant fatty acid type in the liver, mainly due to high DHA and 18:2n6 contents. DHA was more abundant in fish fed on $\mathrm{CT}$ and SCE diets $(p<0.05)$, whereas EPA content was higher in COM group, but only differed significantly from NAN-fed group $(p<0.05)$. Total $\mathrm{n}-3$ content and $\mathrm{n} 3 / \mathrm{n} 6$ ratio were not modified due to dietary treatments. The EPA/DHA ratio was significantly higher in fish fed on COM diet.
The muscle the fatty acid profile was dominated by PUFA (38-45\%), closely followed by SFA (26-30\%) and MUFA (20-24\%) fatty acids, regardless of the diet considered. The saturated fraction was significantly higher $(p<0.05)$ in fish fed on COM diet, mainly due to the higher value for palmitic acid (16:0) observed in this fraction. Total MUFA tended to increase in fish fed on microalgae-free diets, although significant differences were observed only between COM and TISO groups. The inclusion of microalgae biomass in feeds gave a non-significant increase of total PUFA in muscle among feeding groups. The EPA and DHA increased in parallel with total PUFA owing to microalgae inclusion, but again differences were not significant. The $\mathrm{n} 3 / \mathrm{n} 6$

Table 3 Growth performance, nutrient utilization, and somatic indices of S. senegalensis juveniles

\begin{tabular}{lllllrr}
\hline & COM & CT & TISO & NAN & SCE & $P$ \\
\hline Growth and nutrient utilization & & & & & \\
Initial body weight (g) & $11.4 \pm 0.26$ & $11.4 \pm 0.20$ & $11.4 \pm 0.43$ & $11.4 \pm 0.12$ & $11.4 \pm 0.39$ & 0.9984 \\
Final body weight (g) & $29.8 \pm 2.77 \mathrm{a}$ & $47.9 \pm 3.62 \mathrm{~b}$ & $47.7 \pm 4.95 \mathrm{~b}$ & $45.2 \pm 0.28 \mathrm{~b}$ & $45.7 \pm 4.87 \mathrm{~b}$ & 0.0006 \\
Daily gain (DG, mg day ${ }^{-1}$ ) & $0.22 \pm 0.03 \mathrm{a}$ & $0.43 \pm 0.04 \mathrm{~b}$ & $0.43 \pm 0.05 \mathrm{~b}$ & $0.40 \pm 0.01 \mathrm{~b}$ & $0.40 \pm 0.05 \mathrm{~b}$ & 0.0003 \\
Specific growth rate, SGR (\%) & $1.12 \pm 0.09 \mathrm{a}$ & $1.69 \pm 0.08 \mathrm{~b}$ & $1.68 \pm 0.08 \mathrm{~b}$ & $1.63 \pm 0.01 \mathrm{~b}$ & $1.63 \pm 0.08 \mathrm{~b}$ & $<0.0001$ \\
Feed efficiency ratio (FER) & $0.52 \pm 0.05 \mathrm{a}$ & $0.81 \pm 0.06 \mathrm{~b}$ & $0.78 \pm 0.04 \mathrm{~b}$ & $0.77 \pm 0.01 \mathrm{~b}$ & $0.80 \pm 0.05 \mathrm{~b}$ & 0.0001 \\
Feed conversion ratio (FCR) & $1.92 \pm 0.18 \mathrm{~b}$ & $1.24 \pm 0.08 \mathrm{a}$ & $1.28 \pm 0.06 \mathrm{a}$ & $1.30 \pm 0.02 \mathrm{a}$ & $1.26 \pm 0.08 \mathrm{a}$ & $<0.0001$ \\
Protein efficiency ratio (PER) & $0.95 \pm 0.09 \mathrm{a}$ & $1.47 \pm 0.10 \mathrm{~b}$ & $1.42 \pm 0.07 \mathrm{~b}$ & $1.40 \pm 0.02 \mathrm{~b}$ & $1.45 \pm 0.09 \mathrm{~b}$ & 0.0001 \\
Survival (\%) & $96.8 \pm 2.75$ & $88.9 \pm 5.50$ & $90.5 \pm 0.01$ & $92.1 \pm 5.50$ & $95.2 \pm 0.01$ & 0.1129 \\
Somatic indices & & & & & $1.25 \pm 0.34$ & 0.5360 \\
Hepatosomatic index (HIS) & $1.39 \pm 0.40$ & $1.38 \pm 0.40$ & $1.31 \pm 0.29$ & $1.27 \pm 0.40$ & $1.96 \pm 1.46$ & 0.0548 \\
Vicerosomatic index (VI) & $5.05 \pm 0.93$ & $4.31 \pm 0.47$ & $4.47 \pm 0.60$ & $4.49 \pm 1.16$ & 4.96 \\
K-factor & $1.24 \pm 0.14$ & $1.25 \pm 0.11$ & $1.19 \pm 0.11$ & $1.25 \pm 0.15$ & $1.20 \pm 0.12$ & 0.6370 \\
\hline
\end{tabular}

Dietary treatment codes are CT: control; TISO: 15\% Tisochrysis meal inclusion; NAN: 15\% Nannochloropsis meal inclusion; SCE: 15\% Scenedesmus meal inclusion. Values are mean \pm SD of triplicate determination. Values in the same row with different lowercase letter indicate significant difference $(p<0.05)$ 
Table 4 Body chemical composition ( $\mathrm{g} \mathrm{kg}^{-1}$ dry weight) of Senegalese sole juveniles

\begin{tabular}{llll}
\hline & Total protein & Total lipid & Ash \\
\hline COM & $652.6 \pm 30.49$ & $141.95 \pm 16.8 \mathrm{~b}$ & $82.4 \pm 1.07 \mathrm{ab}$ \\
CT & $654.0 \pm 14.40$ & $90.45 \pm 11.1 \mathrm{a}$ & $79.3 \pm 2.11 \mathrm{a}$ \\
TISO & $685.7 \pm 4.13$ & $85.63 \pm 17.3 \mathrm{a}$ & $90.0 \pm 3.17 \mathrm{bc}$ \\
NAN & $682.7 \pm 16.41$ & $99.60 \pm 0.7 \mathrm{a}$ & $91.5 \pm 0.64 \mathrm{c}$ \\
SCE & $671.1 \pm 9.47$ & $74.75 \pm 1.8 \mathrm{a}$ & $86.9 \pm 3.10 \mathrm{~b}$ \\
$P$ & 0.1190 & 0.0180 & 0.0002 \\
\hline
\end{tabular}

Dietary treatment codes are CT: control; TISO: $15 \%$ Tisochrysis meal inclusion; NAN: 15\% Nannochloropsis meal inclusion; SCE: $15 \%$ Scenedesmus meal inclusion. Values are mean \pm SD of triplicate determination. Values in the same column with different lowercase letter indicate significant difference $(p<0.05)$

and EPA/DHA ratios were similar for all experimental groups (Table 6).
Digestive enzyme activity

The activity of pancreatic enzymes total alkaline protease, trypsin, and chymotrypsin did not differ among dietary treatments $(p>0.05)$. The activity of these enzymes was higher $(p<0.05)$ in the intestinal content compared to the intestinal tissue (Table 7). Fish fed on COM diet showed the highest $\alpha$-amylase activity associated to the intestinal tissue, whereas this activity was remarkably low in the intestinal content. Leucine aminopeptidase activity in the intestinal tissue was also lower in fish fed on COM treatment. SCE group displayed higher leucine aminopeptidase activity compared to NAN-fed fish, although no significant differences were found compared to CT group. The comparison of leucine aminopeptidase activities between tissue and content reflected that only SCE-fed fish evidenced noticeable increase of the tissue-associated activity $(p<0.05)$. Regarding alkaline phosphatase, no effect

Table 5 Liver fatty acid composition ( $\%$ fatty acids, mean $\pm \mathrm{SD}, n=3$ ) of Senegalese sole juveniles

\begin{tabular}{|c|c|c|c|c|c|c|}
\hline & $\mathrm{COM}$ & $\mathrm{CT}$ & TISO & NAN & SCE & $P$ \\
\hline $14: 0$ & $5.19 \pm 0.47 \mathrm{~b}$ & $3.70 \pm 0.21 \mathrm{a}$ & $4.71 \pm 0.54 \mathrm{~b}$ & $3.81 \pm 0.27 \mathrm{a}$ & $3.53 \pm 0.44 \mathrm{a}$ & $<0.0001$ \\
\hline $16: 0$ & $21.46 \pm 2.67$ & $19.08 \pm 2.15$ & $19.45 \pm 3.81$ & $19.71 \pm 2.79$ & $19.92 \pm 3.17$ & 0.8441 \\
\hline $18: 0$ & $4.99 \pm 1.40$ & $6.49 \pm 1.52$ & $4.69 \pm 0.92$ & $5.68 \pm 1.28$ & $5.50 \pm 2.45$ & 0.4684 \\
\hline $16: \ln 7$ & $8.34 \pm 0.65 b$ & $5.76 \pm 0.47 \mathrm{a}$ & $7.54 \pm 2.09 \mathrm{ab}$ & $8.57 \pm 0.73 b$ & $5.73 \pm 0.71 \mathrm{a}$ & 0.0029 \\
\hline $18: \ln 9$ & $14.01 \pm 0.82 \mathrm{ab}$ & $14.82 \pm 2.02 b$ & $11.73 \pm 1.94 \mathrm{ab}$ & $10.73 \pm 0.97 \mathrm{a}$ & $12.28 \pm 1.06 \mathrm{ab}$ & 0.0038 \\
\hline $18: \ln 7$ & $4.41 \pm 0.19 \mathrm{ab}$ & $4.15 \pm 0.12 \mathrm{a}$ & $5.09 \pm 0.83 \mathrm{~b}$ & $4.36 \pm 0.25 \mathrm{ab}$ & $4.15 \pm 0.33 \mathrm{a}$ & 0.0141 \\
\hline $20: \ln 9$ & $1.11 \pm 0.31$ & $0.80 \pm 0.36$ & $1.18 \pm 0.18$ & $0.90 \pm 0.30$ & $0.93 \pm 0.34$ & 0.3378 \\
\hline $18: 2 \mathrm{n} 6$ & $7.45 \pm 0.89 \mathrm{a}$ & $10.53 \pm 0.65 \mathrm{ab}$ & $10.26 \pm 2.81 \mathrm{ab}$ & $11.87 \pm 0.72 b$ & $10.13 \pm 1.32 \mathrm{ab}$ & 0.0335 \\
\hline $18: 3 n 3$ & $1.48 \pm 0.27 \mathrm{bc}$ & $0.73 \pm 0.28 \mathrm{a}$ & $1.05 \pm 0.24 \mathrm{ab}$ & $0.88 \pm 0.29 \mathrm{ab}$ & $1.78 \pm 0.46 \mathrm{c}$ & 0.0006 \\
\hline $20: 4 n 6$ (ARA) & $1.74 \pm 0.36$ & $2.48 \pm 0.62$ & $2.42 \pm 0.59$ & $2.99 \pm 0.46$ & $2.43 \pm 0.64$ & 0.1046 \\
\hline 20:5n3 (EPA) & $2.25 \pm 0.06 \mathrm{~b}$ & $1.51 \pm 0.41 \mathrm{ab}$ & $1.34 \pm 0.23 \mathrm{ab}$ & $1.24 \pm 0.40 \mathrm{a}$ & $1.64 \pm 0.54 \mathrm{ab}$ & 0.0433 \\
\hline $22: 5 n 3$ & $6.83 \pm 0.56$ & $5.54 \pm 1.72$ & $5.39 \pm 2.82$ & $6.97 \pm 1.50$ & $5.14 \pm 2.23$ & 0.5398 \\
\hline 22:6n3 (DHA) & $13.30 \pm 1.32 \mathrm{a}$ & $17.98 \pm 2.43 b$ & $14.93 \pm 2.82 \mathrm{a}$ & $16.29 \pm 0.98 \mathrm{ab}$ & $18.83 \pm 1.49 \mathrm{~b}$ & 0.0031 \\
\hline SFA & $31.64 \pm 3.53$ & $29.27 \pm 3.47$ & $28.84 \pm 5.00$ & $29.21 \pm 4.23$ & $28.95 \pm 5.25$ & 0.9115 \\
\hline MUFA & $27.87 \pm 0.76$ & $25.53 \pm 2.26$ & $25.54 \pm 4.41$ & $24.34 \pm 0.91$ & $23.09 \pm 1.22$ & 0.1437 \\
\hline PUFA & $33.04 \pm 1.43$ & $38.77 \pm 4.49$ & $35.39 \pm 4.81$ & $40.25 \pm 1.96$ & $39.95 \pm 4.71$ & 0.1853 \\
\hline Other FA & $3.90 \pm 2.20$ & $2.44 \pm 1.14$ & $6.06 \pm 2.89$ & $4.63 \pm 1.81$ & $4.89 \pm 2.10$ & 0.0979 \\
\hline n3 & $23.85 \pm 1.40$ & $25.75 \pm 4.35$ & $22.71 \pm 3.99$ & $25.39 \pm 1.86$ & $27.39 \pm 4.08$ & 0.6167 \\
\hline n6 & $9.19 \pm 0.76 \mathrm{a}$ & $13.01 \pm 1.12 \mathrm{~b}$ & $12.68 \pm 2.47 \mathrm{~b}$ & $14.86 \pm 1.01 \mathrm{~b}$ & $12.56 \pm 0.90 \mathrm{~b}$ & 0.0017 \\
\hline n9 & $15.12 \pm 0.53 \mathrm{~b}$ & $15.62 \pm 2.24 \mathrm{~b}$ & $12.91 \pm 2.03 \mathrm{ab}$ & $11.41 \pm 0.59 \mathrm{a}$ & $13.21 \pm 0.83 \mathrm{ab}$ & 0.0038 \\
\hline $\mathrm{n} 3 / \mathrm{n} 6$ & $1.39 \pm 0.04 \mathrm{a}$ & $1.52 \pm 0.11 \mathrm{ab}$ & $1.57 \pm 0.16 b$ & $1.59 \pm 0.07 \mathrm{ab}$ & $1.46 \pm 0.05 \mathrm{ab}$ & 0.0238 \\
\hline EPA/DHA & $0.17 \pm 0.01 \mathrm{~b}$ & $0.08 \pm 0.02 \mathrm{a}$ & $0.09 \pm 0.01 \mathrm{a}$ & $0.08 \pm 0.03 \mathrm{a}$ & $0.09 \pm 0.03 \mathrm{a}$ & 0.0003 \\
\hline
\end{tabular}

Dietary treatment codes are CT: control; TISO: 15\% Tisochrysis meal inclusion; NAN: 15\% Nannochloropsis meal inclusion; SCE: 15\% Scenedesmus meal inclusion. Values in the same row with different lowercase letter indicate significant difference $(p<0.05)$ 
Table 6 Muscle fatty acid composition ( $\%$ fatty acids, mean $\pm \mathrm{SD}, n=3$ ) of Senegalese sole juveniles

\begin{tabular}{|c|c|c|c|c|c|c|}
\hline & $\mathrm{COM}$ & $\mathrm{CT}$ & TISO & NAN & SCE & $P$ \\
\hline $14: 0$ & $3.03 \pm 0.22$ & $2.59 \pm 0.32$ & $2.89 \pm 0.25$ & $2.39 \pm 0.44$ & $2.52 \pm 0.52$ & 0.0539 \\
\hline $16: 0$ & $20.25 \pm 1.06 \mathrm{c}$ & $18.57 \pm 0.66 \mathrm{~b}$ & $18.22 \pm 0.37 \mathrm{ab}$ & $17.87 \pm 0.76 \mathrm{ab}$ & $17.39 \pm 0.32 \mathrm{a}$ & 0.0001 \\
\hline 18:0 & $7.54 \pm 0.92$ & $6.29 \pm 0.91$ & $6.29 \pm 0.08$ & $6.37 \pm 0.88$ & $6.11 \pm 1.02$ & 0.1988 \\
\hline $16: \ln 7$ & $5.29 \pm 0.56 \mathrm{ab}$ & $4.70 \pm 0.56 \mathrm{ab}$ & $5.57 \pm 0.66 \mathrm{ab}$ & $5.14 \pm 1.04 b$ & $4.51 \pm 0.91 \mathrm{a}$ & 0.0218 \\
\hline $18: \ln 9$ & $14.70 \pm 0.86 \mathrm{c}$ & $13.42 \pm 0.48 b c$ & $11.39 \pm 0.83 \mathrm{a}$ & $12.43 \pm 1.11 \mathrm{a}$ & $13.32 \pm 0.29 b$ & $<0.0001$ \\
\hline $18: \ln 7$ & $3.01 \pm 0.07$ & $2.83 \pm 0.14$ & $2.89 \pm 0.10$ & $2.92 \pm 0.11$ & $2.88 \pm 0.06$ & 0.1926 \\
\hline $20: \ln 9$ & $1.61 \pm 0.71$ & $1.97 \pm 1.05$ & $0.87 \pm 0.27$ & $1.24 \pm 0.80$ & $1.39 \pm 0.72$ & 0.3033 \\
\hline $18: 2 \mathrm{n} 6$ & $5.36 \pm 0.12 \mathrm{a}$ & $7.23 \pm 0.28 b$ & $7.24 \pm 0.85 b$ & $7.77 \pm 0.66 \mathrm{c}$ & $7.29 \pm 0.37 b$ & $<0.0001$ \\
\hline $18: 3 n 3$ & $1.26 \pm 0.12 \mathrm{ab}$ & $0.82 \pm 0.18 \mathrm{a}$ & $0.97 \pm 0.16 \mathrm{a}$ & $2.00 \pm 2.05 \mathrm{a}$ & $2.95 \pm 2.46 \mathrm{~b}$ & 0.0041 \\
\hline $20: 4 n 6$ (ARA) & $1.38 \pm 0.46 \mathrm{a}$ & $1.71 \pm 0.19 \mathrm{a}$ & $1.83 \pm 0.18 \mathrm{ab}$ & $2.00 \pm 0.47 b$ & $1.65 \pm 0.35 \mathrm{a}$ & 0.0008 \\
\hline $20: 5 n 3$ (EPA) & $4.34 \pm 1.83$ & $4.25 \pm 1.14$ & $5.36 \pm 0.40$ & $4.64 \pm 1.18$ & $4.40 \pm 1.20$ & 0.6283 \\
\hline $22: 5 n 3$ & $5.76 \pm 1.84$ & $5.06 \pm 1.47$ & $6.93 \pm 0.56$ & $6.30 \pm 1.62$ & $5.85 \pm 1.39$ & 0.3259 \\
\hline $22: 6 n 3(\mathrm{DHA})$ & $20.02 \pm 4.62$ & $21.04 \pm 4.61$ & $22.20 \pm 4.55$ & $22.81 \pm 5.03$ & $23.82 \pm 6.17$ & 0.8518 \\
\hline SFA & $30.82 \pm 2.06 \mathrm{~b}$ & $27.46 \pm 1.33 \mathrm{a}$ & $27.40 \pm 0.61 \mathrm{a}$ & $26.63 \pm 1.12 \mathrm{a}$ & $26.02 \pm 0.79 \mathrm{a}$ & 0.0005 \\
\hline MUFA & $24.61 \pm 1.09 \mathrm{~b}$ & $22.92 \pm 1.81 \mathrm{ab}$ & $20.72 \pm 1.27 \mathrm{a}$ & $21.61 \pm 1.55 \mathrm{ab}$ & $21.87 \pm 1.44 \mathrm{ab}$ & 0.0299 \\
\hline PUFA & $38.11 \pm 8.02$ & $40.12 \pm 6.84$ & $44.54 \pm 4.00$ & $45.51 \pm 5.90$ & $45.96 \pm 6.42$ & 0.3208 \\
\hline Other FA & $1.20 \pm 0.71$ & $3.56 \pm 1.56$ & $4.78 \pm 3.32$ & $3.52 \pm 0.26$ & $2.86 \pm 1.27$ & 0.0520 \\
\hline$n-3$ & $31.38 \pm 8.28$ & $31.18 \pm 7.01$ & $35.46 \pm 4.33$ & $35.74 \pm 6.00$ & $37.02 \pm 6.02$ & 0.5473 \\
\hline$n-6$ & $6.73 \pm 0.39 \mathrm{a}$ & $8.95 \pm 0.23 b$ & $9.08 \pm 0.69 b$ & $9.77 \pm 1.04 \mathrm{c}$ & $8.95 \pm 0.48 b$ & $<0.0001$ \\
\hline$n-9$ & $16.31 \pm 1.54 \mathrm{~b}$ & $15.39 \pm 1.45 b$ & $12.26 \pm 0.56 \mathrm{a}$ & $13.56 \pm 1.53 \mathrm{a}$ & $14.49 \pm 0.89 \mathrm{ab}$ & 0.0002 \\
\hline $\mathrm{n} 3 / \mathrm{n} 6$ & $1.23 \pm 0.07$ & $1.30 \pm 0.09$ & $1.26 \pm 0.05$ & $1.28 \pm 0.08$ & $1.25 \pm 0.04$ & 0.2608 \\
\hline EPA/DHA & $0.21 \pm 0.05$ & $0.20 \pm 0.03$ & $0.25 \pm 0.08$ & $0.20 \pm 0.04$ & $0.19 \pm 0.04$ & 0.2566 \\
\hline
\end{tabular}

Dietary treatment codes are CT: control; TISO: 15\% Tisochrysis meal inclusion; NAN: 15\% Nannochloropsis meal inclusion; SCE: 15\% Scenedesmus meal inclusion. Values in the same row with different lowercase letter indicate significant difference $(p<0.05)$

was attributable to the use of microalgae in intestinal tissue extracts when compared to CT group. COM-fed fish showed lower activity in tissue compared to fish fed CT and SCE diets. Microalgae-supplemented groups exhibited lower alkaline phosphatase activity in intestine content than fish-fed CT diet.

Zimograms revealed that microalgae inclusion did not modify the intestinal protease pattern of active bands in Senegalese sole juveniles when compared to CT fish (Fig. 2). COM-fed specimens showed lower number of active bands.

Histological examination of the liver and intestine

The histological characteristics of liver sections from fish fed the different dietary treatments are shown in Fig. 3. No severe evidence of necrosis or steatosis was found. Overall, all fish exhibited normal-shaped hepatocytes with regular morphology. Nevertheless, moderate hepatocyte vacuolization was observed in several samples of fish fed CT diet. The morphological study by light microscopy revealed that fish fed on microalgae-supplemented diets showed smaller hepatocytes than fish fed on CT diet, albeit SCE group showed higher hepatocyte area than fish included in TISO or NAN groups (Table 8). Hepatocytes of fish fed on COM diet were significantly smaller compared to the other dietary groups.

COM-fed fish showed signs of damage and morphological alterations in the intestinal mucosa (Fig. 4). Enterocytes presented a marked vacuolization grade, and intestinal folds evidenced a clear inflammatory signs, as may be deduced from the presence of infiltrated leucocytes in the lamina propria. In some extreme cases, big lipid droplets almost took up the entire cell, displacing the nucleus and the cellular components towards the periphery. Neither CT-fed fish, nor microalgae-supplemented specimens revealed signs of intestinal damage. At most, a slightly increased accumulation of lipid droplets in fish fed on the microalgae- 
Table 7 Enzyme activities ( $\mathrm{U}$ tissue ${ }^{-1}$ ) measured in intestine of Senegalese sole juveniles

\begin{tabular}{|c|c|c|c|c|c|c|}
\hline & $\mathrm{COM}$ & $\mathrm{CT}$ & TISO & NAN & SCE & $P$ \\
\hline \multicolumn{7}{|l|}{ Tissue } \\
\hline Total alkaline protease & $96.5 \pm 22.1 \mathrm{z}$ & $114.3 \pm 51.1 \mathrm{z}$ & $122.5 \pm 50.7 \mathrm{z}$ & $113.9 \pm 56.0 \mathrm{z}$ & $114.3 \pm 51.1 \mathrm{z}$ & 0.0937 \\
\hline Trypsin & $0.04 \pm 0.01 \mathrm{z}$ & $0.04 \pm 0.01 \mathrm{z}$ & $0.04 \pm 0.01 \mathrm{z}$ & $0.04 \pm 0.01 \mathrm{z}$ & $0.04 \pm 0.01 \mathrm{z}$ & 0.5196 \\
\hline Chymotrypsin & $0.04 \pm 0.01 \mathrm{z}$ & $0.04 \pm 0.02 \mathrm{z}$ & $0.05 \pm 0.01 \mathrm{z}$ & $0.04 \pm 0.01 \mathrm{z}$ & $0.04 \pm 0.01 \mathrm{z}$ & 0.4257 \\
\hline$\alpha$-Amylase & $0.27 \pm 0.17 \mathrm{a}, \mathrm{y}$ & $0.35 \pm 0.09 \mathrm{ab}$ & $0.52 \pm 0.16 b$ & $0.52 \pm 0.19 a b$ & $0.34 \pm 0.18 \mathrm{ab}$ & 0.0247 \\
\hline L-aminopeptidase & $0.12 \pm 0.04 \mathrm{a}, \mathrm{z}$ & $0.28 \pm 0.06 \mathrm{bc}$ & $0.28 \pm 0.08 \mathrm{bc}$ & $0.25 \pm 0.08 \mathrm{~b}$ & $0.40 \pm 0.12 \mathrm{c}, \mathrm{y}$ & $<0.0001$ \\
\hline Alkaline phosphatase & $1.42 \pm 0.57 \mathrm{a}, \mathrm{z}$ & $2.89 \pm 0.98 \mathrm{~b}, \mathrm{z}$ & $2.31 \pm 0.38 \mathrm{ab}$ & $2.14 \pm 0.62 \mathrm{ab}$ & $3.17 \pm 0.76 \mathrm{~b}$ & 0.0004 \\
\hline \multicolumn{7}{|l|}{ Content } \\
\hline Total alkaline protease & $609.3 \pm 104.9 y$ & $752.3 \pm 200.8 \mathrm{y}$ & $583.9 \pm 137.9$ y & $663.2 \pm 242.5 \mathrm{y}$ & $598.5 \pm 122.5 \mathrm{y}$ & 0.2652 \\
\hline Trypsin & $0.20 \pm 0.07 \mathrm{y}$ & $0.11 \pm 0.06 \mathrm{y}$ & $0.12 \pm 0.04 \mathrm{y}$ & $0.15 \pm 0.08 \mathrm{y}$ & $0.15 \pm 0.093 \mathrm{y}$ & 0.1019 \\
\hline Chymotrypsin & $4.05 \pm 0.98 \mathrm{y}$ & $4.07 \pm 2.25 \mathrm{y}$ & $4.43 \pm 1.50 \mathrm{y}$ & $5.59 \pm 1.16 \mathrm{y}$ & $3.39 \pm 1.03 \mathrm{y}$ & 0.0543 \\
\hline$\alpha$-Amylase & $0.11 \pm 0.04 \mathrm{a}, \mathrm{z}$ & $0.39 \pm 0.12 b$ & $0.36 \pm 0.17 \mathrm{~b}$ & $0.41 \pm 0.02 \mathrm{~b}$ & $0.39 \pm 0.14 b$ & 0.0043 \\
\hline L-aminopeptidase & $0.30 \pm 0.06 \mathrm{y}$ & $0.27 \pm 0.10$ & $0.28 \pm 0.14$ & $0.16 \pm 0.11$ & $0.21 \pm 0.12 \mathrm{z}$ & 0.1274 \\
\hline Alkaline phosphatase & $7.18 \pm 2.44 \mathrm{ab}, \mathrm{y}$ & $9.21 \pm 3.48 \mathrm{~b}, \mathrm{y}$ & $3.24 \pm 1.57 \mathrm{a}$ & $3.66 \pm 1.31 \mathrm{a}$ & $4.51 \pm 1.90 \mathrm{a}$ & 0.0011 \\
\hline
\end{tabular}

Dietary treatments are COM: commercial diet, CT: control diet; TISO: 15\% Tisochrysis inclusion; NAN: 15\% Nannochloropsis inclusion; SCE: $15 \%$ Scenedesmus inclusion. Values are mean \pm SD of triplicate determination. Values in the same row with different lowercase letter $(\mathrm{a}, \mathrm{b}, \mathrm{c})$ indicate significant differences among treatments $(p<0.05)$. Values in the same column with different lower case letter $(\mathrm{y}, \mathrm{z})$ indicate significant differences between tissue and content for the same activity within each dietary treatment $(p<0.05)$

supplemented diets was observed. COM diet decreased significantly the intestinal fold length compared to fish

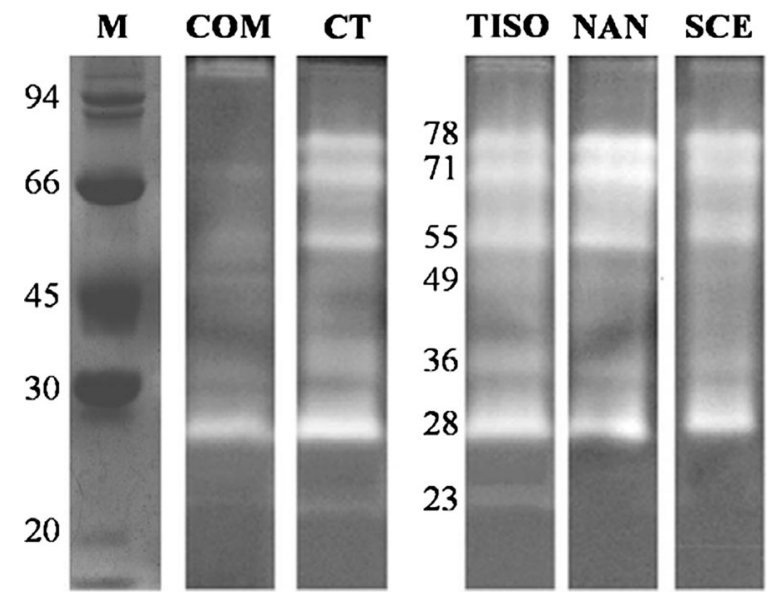

Fig. 2 Zymogram showing total proteolytic activity from pooled intestinal extracts of fish. $\mathrm{M}$ is molecular weight marker, COM is commercial diet, CT is control diet, TISO is $15 \%$ T. lutea, NAN is $15 \%$ N. gaditana, and SCE is $15 \%$ S. almeriensis. Protein standards employed were phosphorylase b (94), bovine serum albumin (66), ovalbumin (45), carbonic anhydrase (30), soybean trypsin inhibitor (20). The molecular mass (in $\mathrm{kDa}$ ) of proteins was measured using a linear plot of log Mr. of protein standards (M) vs relative mobility (Rf). Five microliters of molecular weight marker (M) were loaded fed on the rest of diets (Table 8). Moreover, fish fed on TISO and SCE diets showed slightly higher fold length than NAN and CT-fed fish, although differences were not significant. No differences among fish-fed microalgae-supplemented diets and fish-fed CT diet with regard to the parameter enterocyte height were observed. On the other hand, animals fed on COM diet exhibited significantly higher enterocyte height compared to those fed on CT diet.

Ultraestructural study

TEM observations confirmed that none of the dietary treatments damaged the brush border integrity of enterocytes (Fig. 5). All the experimental groups presented a well-defined and organized intestinal brush border membrane. Moreover, no intercellular spaces were visible in the apical zone of the epithelium. TISO and NAN-fed fish showed significantly longer microvilli than fish fed on microalgae-free diets (Table 9). The microvillar density and the absorption surface tended to increase in microalgae-fed fish, although values were significantly higher only in TISO group for the first parameter, and in TISO and NAN groups for the second parameter. 


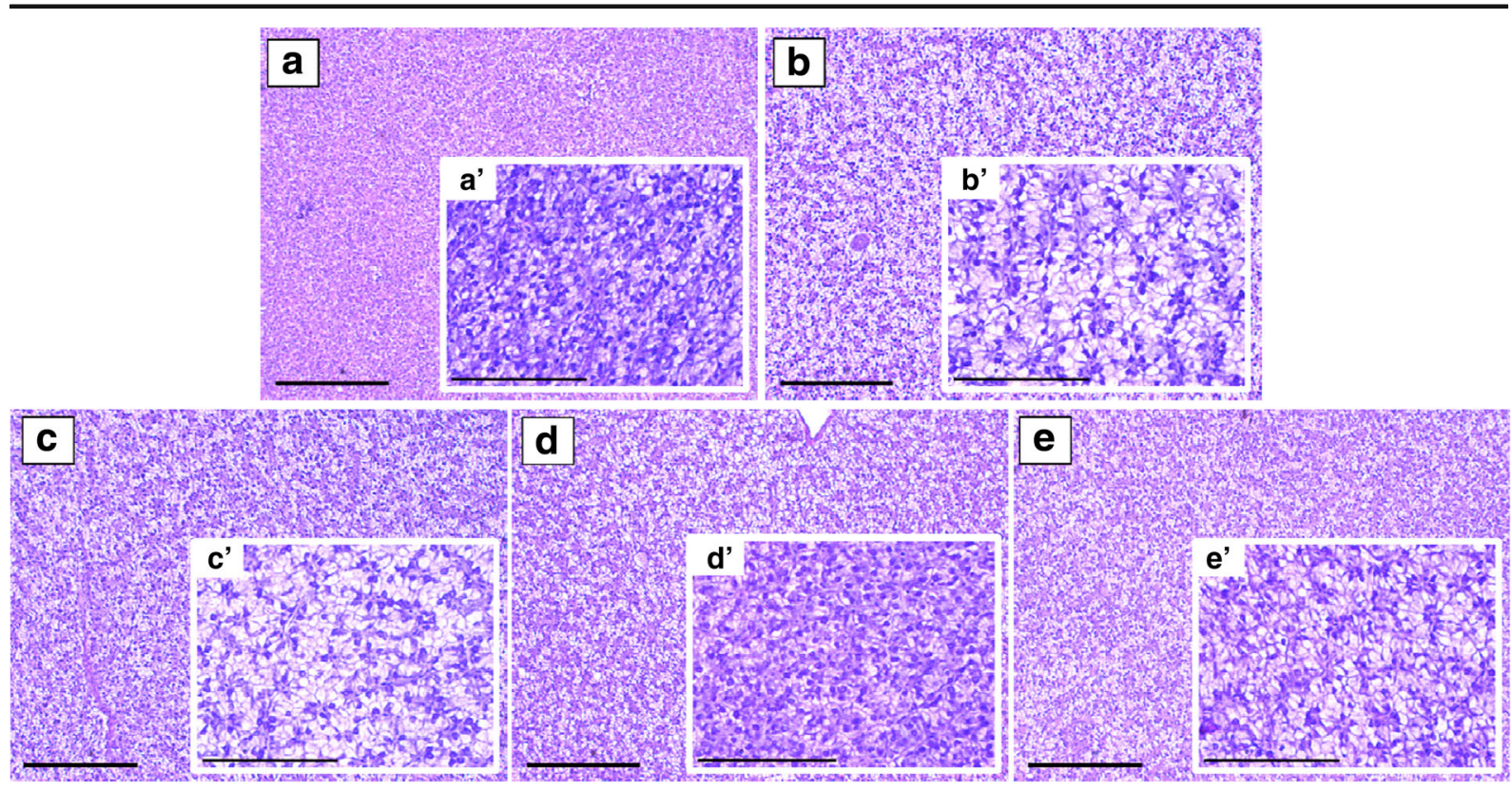

Fig. 3 Liver light microscopy details of Senegalese sole juveniles fed COM (a), CT (b); TISO (c); NAN (d), and SCE (e) diets. H\&E stain, magnification $\times 100\left(\mathbf{a}, \mathbf{b}, \mathbf{c}, \mathbf{d}\right.$, and e) scale bar $200 \mu \mathrm{m}$, and $\times 400\left(\mathrm{a}^{\prime}, \mathrm{b}^{\prime}, \mathrm{c}^{\prime}, \mathrm{d}^{\prime}\right.$, and e') scale bar $100 \mu \mathrm{m}$

\section{Discussion}

Microalgae meal has been successfully included in diets for several fish species, such as rainbow trout, gilthead sea bream or European sea bass (Teimouri et al. 2013; Vizcaíno et al. 2014; Tibaldi et al. 2015) without evidence of negative effect on growth performance or nutrient utilization. The results obtained in the present study confirmed that microalgae inclusion up to $15 \%$ did not cause adverse effects on Senegalese sole juveniles, given that growth performance parameters were similar to those found in CTfed fish. In contrast, growth was lower in fish fed on a commercial diet (COM). Incorporation of plant ingredients in partial replacement of fishmeal is a well-established practice in commercial aquafeed production (Valente et al. 2011; Rodiles et al. 2015), though it may have negative effects on fish (Sáenz de Rodrigáñez et al. 2009). On the contrary, $\mathrm{CT}$ and microalgae-supplemented diets are practically devoid of plant-derived ingredients, which might explain better zootechnical indices. Given that the inclusion of microalgae does not jeopardize fish growth, it seems that microalgae could be a suitable dietary ingredient for this species, as also has been reported by several authors (Burr et al. 2011; Reitan et al. 2013; Tibaldi et al. 2015; Kiron et al. 2016; Sorensen et al. 2016).

Table 8 Quantification of the histological parameters assessed in the liver and the intestine at the end of feeding trial

\begin{tabular}{|c|c|c|c|c|c|c|}
\hline & $\mathrm{COM}$ & $\mathrm{CT}$ & TISO & NAN & SCE & $P$ \\
\hline \multicolumn{7}{|l|}{ Liver } \\
\hline Hepatocyte area $\left(\mu \mathrm{m}^{2}\right)$ & $41.2 \pm 8.91 \mathrm{a}$ & $78.1 \pm 11.5 \mathrm{~d}$ & $53.4 \pm 13.9 \mathrm{~b}$ & $64.4 \pm 9.87 \mathrm{c}$ & $71.9 \pm 8.64 \mathrm{~d}$ & $<0.0001$ \\
\hline Hepatocyte major axis $(\mu \mathrm{m})$ & $8.76 \pm 1.24 \mathrm{a}$ & $11.1 \pm 0.97 \mathrm{c}$ & $9.81 \pm 0.97 \mathrm{~b}$ & $9.88 \pm 0.92 b$ & $10.1 \pm 0.81 \mathrm{~b}$ & $<0.0001$ \\
\hline \multicolumn{7}{|l|}{ Intestine } \\
\hline Fold length $(\mu \mathrm{m})$ & $408.7 \pm 109.7 \mathrm{a}$ & $535.6 \pm 71.8 \mathrm{bc}$ & $547.4 \pm 114.2 \mathrm{bc}$ & $496.5 \pm 89.1 \mathrm{~b}$ & $564.9 \pm 98.3 \mathrm{c}$ & 0.0290 \\
\hline Enterocyte height $(\mu \mathrm{m})$ & $39.2 \pm 3.53 b$ & $25.4 \pm 2.31 \mathrm{a}$ & $26.5 \pm 3.38 \mathrm{a}$ & $26.2 \pm 3.08 \mathrm{a}$ & $26.9 \pm 2.39 \mathrm{a}$ & $<0.0001$ \\
\hline
\end{tabular}

Dietary treatment codes are CT: control; TISO: 15\% Tisochrysis meal inclusion; NAN: 15\% Nannochloropsis meal inclusion; SCE: 15\% Scenedesmus meal inclusion. Values are mean \pm SD of triplicate determination. Values in the same row with different lowercase letter indicate significant differences $(p<0.05)$ 


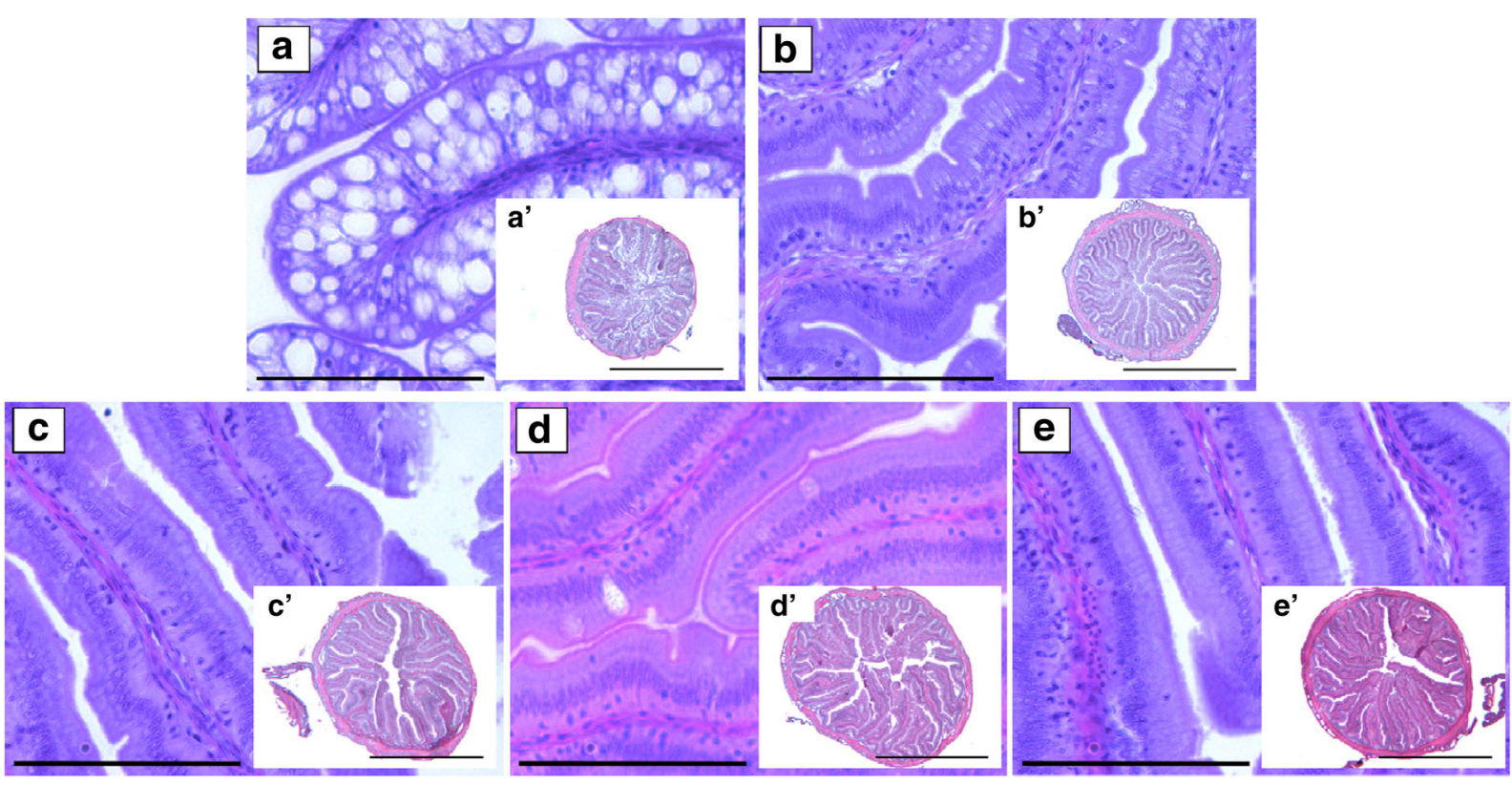

Fig. 4 Intestine light microscopy details of Senegalese sole juveniles fed COM (a), CT (b), TISO (c), NAN (d), and SCE (e) diets. H\&E stain, magnification $\times 400\left(\mathbf{a}, \mathbf{b}, \mathbf{c}, \mathbf{d}\right.$, and e) scale bar $100 \mu \mathrm{m}$, and $\times 40\left(\mathrm{a}^{\prime}, \mathrm{b}^{\prime}, \mathrm{c}^{\prime}, \mathrm{d}^{\prime}\right.$, and e') scale bar $1 \mathrm{~mm}$

The lipid content of CT, TISO, NAN, and SCE diets was lower $(9-10 \%)$ than that found in COM (15\%). This observation may explain the reduced growth in fish fed on COM diet. Indeed, the contribution of dietary lipid as energy-yielding substrate is not clearly ascertained for Senegalese sole. Dias et al. (2004) suggested an overall tendency to improve growth performance in Senegalese sole juveniles fed low dietary lipid level. The reduced growth of fish fed the COM diet may be explained by the high
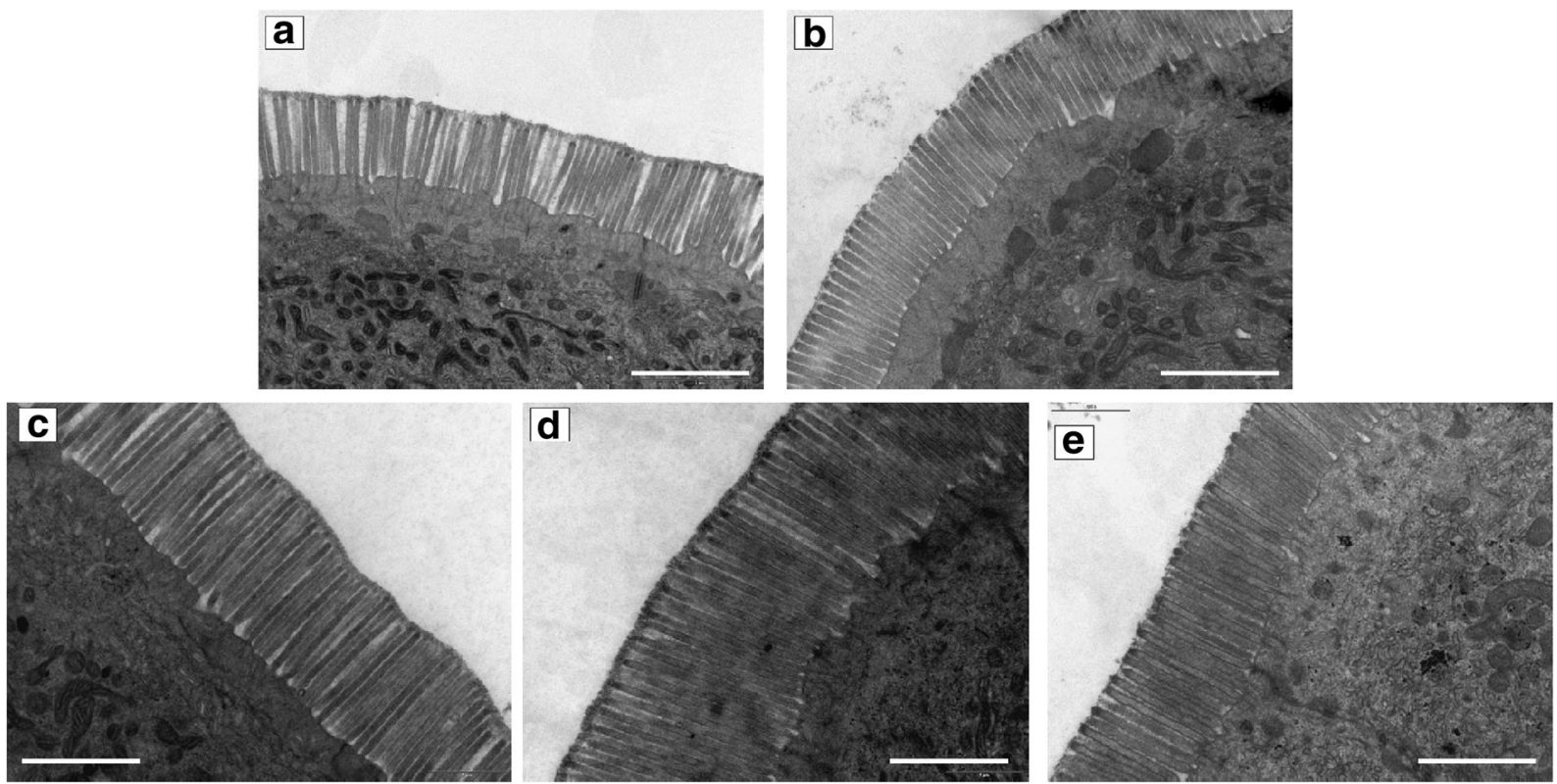

Fig. 5 Comparative TEM micrographs from the anterior intestinal region of juvenile $S$. senegalensis fed COM (a), CT (b), TISO (c), NAN (d), and SCE (e) diets. TEM bar scale, $2 \mu \mathrm{m}$ 
Table 9 Microvilli morphology of the anterior intestine at the end of the feeding trial

\begin{tabular}{lllll}
\hline & Microvilli length $(\mu \mathrm{m})$ & Microvilli diameter $(\mu \mathrm{m})$ & $\mathrm{N}^{\circ}$ microvilli $\mu \mathrm{m}^{2}$ & ${\text { Microvilli absorption surface }\left(\mu \mathrm{m}^{2}\right)}$ \\
\hline $\mathrm{COM}$ & $1.33 \pm 0.10 \mathrm{a}$ & $0.10 \pm 0.01$ & $64.49 \pm 11.32 \mathrm{a}$ & $27.50 \pm 1.70 \mathrm{a}$ \\
$\mathrm{CT}$ & $1.38 \pm 0.17 \mathrm{a}$ & $0.10 \pm 0.01$ & $61.93 \pm 12.12 \mathrm{a}$ & $28.80 \pm 3.25 \mathrm{a}$ \\
TISO & $1.57 \pm 0.16 \mathrm{~b}$ & $0.10 \pm 0.01$ & $76.60 \pm 10.17 \mathrm{~b}$ & $39.14 \pm 3.44 \mathrm{~b}$ \\
$\mathrm{NAN}$ & $1.99 \pm 0.25 \mathrm{c}$ & $0.10 \pm 0.01$ & $70.57 \pm 9.80 \mathrm{ab}$ & $45.93 \pm 3.68 \mathrm{c}$ \\
$\mathrm{SCE}$ & $1.35 \pm 0.25 \mathrm{a}$ & $0.10 \pm 0.01$ & $66.78 \pm 15.66 \mathrm{a}$ & $26.30 \pm 10.41 \mathrm{a}$ \\
$P$ & $<0.0001$ & 0.0616 & $<0.0001$ & $<0.0001$ \\
\hline
\end{tabular}

Dietary treatment codes are CT: control; TISO: 15\% Tisochrysis meal inclusion; NAN: 15\% Nannochloropsis meal inclusion; SCE: 15\% Scenedesmus meal inclusion. Values are mean \pm SD of triplicate determination. Values in the same column with different lowercase letter indicate significant differences $(p<0.05)$

lipid level. The optimal dietary lipid content is not well established for Senegalese sole. However, earlier research has reported improved growth in Senegalese sole juveniles $(10 \mathrm{~g})$, when fed $8 \%$ lipid in the diet compared to $16 \%$ (Borges et al. 2009). In agreement, Valente et al. (2011) noticed the absence of hepatic morphological alteration in fish fed diets with low dietary lipid level, compared to specimens fed on an experimental diet based on a commercial diet for sole, which included $15 \%$ crude lipid. Reduced protein efficiency due to increasing amounts of dietary lipids has also been reported in turbot (Regost et al. 2001). Borges et al. (2009) suggested a maximum dietary lipid level around $8 \%$ for optimal growth and nutrient utilization in Senegalese sole juveniles. Lipid content of CT and microalgae-supplemented diets used in the present study are closer to that recommended value, whereas COM diet clearly exceeds it.

The higher lipid content of COM diet was also reflected in the proximate composition of fish carcasses. Body lipid content was higher in fish fed on COM, which is in agreement with previous studies carried out on other flatfish species, such as turbot and Atlantic halibut (Andersen and Alsted 1993; Regost et al. 2001).

According to Fernandes et al. (2012), the study of fatty acid composition is essential to understand the influence of feed composition on the chemical profile of fish. Results revealed that specific fatty acids were selectively retained in Senegalese sole tissues. This observation is in line with other studies carried out in the same species by Valente et al. (2011) and Rodiles et al. (2015). High DHA content in muscle when fish were fed low dietary level of this fatty acid has been also reported in $S$. senegalensis juveniles (Fernandes et al.
2012; Rodiles et al. 2015), and other flatfish (Martins et al. 2007). This observation suggested certain selective storage of this fatty acid in fish tissues. On the contrary, the muscle EPA retention was lower compared to DHA and ARA, which suggests higher catabolic use of EPA (Bell et al. 2002) and/or a preferential retention of DHA and ARA during the biosynthesis of phospholipids (Tocher 2003).

Adequate fish growth corresponds to efficient nutrient digestion and absorption processes, which relies greatly on the activity of digestive enzymes. Pancreatic and intestinal brush border enzymes are correlated with the nutritional status of fish (Alarcón et al. 1998). Hence, their activities can be used as indicators of the digestive and absorptive capacity of fish (Vizcaíno et al. 2014, 2016). The present work confirmed that none of the microalgae added to the experimental feeds caused adverse effects on the activity of the digestive enzymes studied. As expected, proteolytic activities from the pancreatic secretion were higher in gut contents, given that these enzymes are secreted into the intestinal lumen, contributing to the digestion of protein into peptides and amino acids. The pattern of proteolytic bands visualized by SDS-PAGE zymography was similar in CT, TISO, NA, and SCE groups. However, in COM-fed fish the protease active fractions within the range from 36 to $78 \mathrm{kDa}$ showed a different pattern, suggesting that the digestive capacity of fish was reduced compared to the other dietary treatments. Nevertheless, neither microalgae nor commercial or experimental diets contained protease inhibitors that inhibited intestinal proteases (pers. comm.).

The chemical nature of carbohydrates might influence the intestinal amylase secretion in fish (Chen 
et al. 2013). These authors reported positive correlation between amylopectin content and amylase activity. Amylopectin allows a greater access to digestive enzymes than amylose. The decreased amylase activity in the intestinal content of the COM-fed fish might be explained by the use of different carbohydrates as binders. COM feed contained wheat, whereas the experimental diets included maltodextrin. Several authors have reported that amylase activity depends on starch sources, inclusion level and processing intensity of the starch (Kumar et al. 2008; Liu et al. 2014; Frías-Quintana et al. 2017). However, in the case of Senegalese sole previous research focused on this specific topic is not available and, consequently, no definitive conclusions can be drawn.

With regard to brush border membrane enzyme activities, microalgae inclusion did not modify leucine aminopeptidase activity measured in the intestinal tissue compared to CT-fed fish. However, SCEfed specimens showed slightly higher values for this activity, which may be related to increased intestinal absorptive capacity, as described in previous studies (Vizcaíno et al. 2014, 2016). On the other hand, alkaline phosphatase activity decreased in the intestinal content of fish fed on microalgae-supplemented diets, which might reflect changes in the physiological status of the intestine to certain extent. The quantitative change in the spatial distribution of specific enzymes involved in the absorption processes might indicate that microalgae could modulate the functionality of the intestine in S. senegalensis, as it has been reported in seabream (Vizcaíno et al. 2014, 2016). Further studies will be requested to fully ascertain this aspect in Senegalese sole.

Liver histology revealed the lack of alterations in the structure and morphology in any of the experimental groups evaluated. However, these results disagree with those reported by Valente et al. (2011), who indicated that the replacement of fishmeal by a mixture of plant protein ingredients increased vacuolization and necrosis signs in hepatocytes of Senegalese sole. Therefore, the histological and ultrastructural study of the intestinal mucosa is a key tool that helps understand how dietary changes could affect this organ. Histological observation of fish receiving COM diet showed large lipid droplets inside the enterocytes that increased significantly their size. Excessive accumulation of lipidic droplets might lead to functional alterations of the enterocytes (Olsen et al. 2000), that might compromise fish growth and nutrient utilization. Moreover, tissue damage and altered gut integrity may increase the risk of a potential microbial infection (Sáenz de Rodrigáñez et al. 2009). In contrast, enterocytes of fish receiving microalgae-supplemented and CT diets presented normal characteristics in this work. The lack of adverse effects due to dietary inclusion of microalgae confirmed the ability of Senegalese sole to cope with diets containing low levels of fishmeal, in agreement with some previous studies (Cabral et al. 2011; Fernandes et al. 2012; Rodiles et al. 2015). It is presumed that enterocytes with normal appearance have a better functionality than those enterocytes of COM-fed group with an altered morphology. In addition, the greater fold length observed in fish fed CT, TISO, NAN, and SCE diets could be considered a sign of improved intestinal absorption capacity in these specimens, according to what has been reported in different fish species (Hussein et al. 2013; Vizcaíno et al. 2014).

Nevertheless, in the present study, increased villi length seems not to be directly associated with the dietary inclusion of microalgae. Electron microscopy analysis of the intestinal brush border did not evidence negative structural alterations attributable to the dietary inclusion of microalgae, and microvilli length and microvillar absorptive surface significantly increased in specimens fed TISO and NANsupplemented diets.

The dietary inclusion of $15 \%$ microalgae in Senegalese sole juveniles yielded similar results in terms of specific growth rate, feed conversion, and well as proximate and fatty acid composition compared with fish fed on a diet based on fishmeal. The ultrastructural study revealed that the inclusion of microalgae, especially T. lutea and N. galbana, increased significantly the absorptive capacity of the intestinal mucosa of fish. Given that the production of microalgae is still very expensive, the use of these microalgae as a major feed ingredient is hardly recommendable in Senegalese sole juveniles. However, further studies aimed to assess its potential use in diets devoid of animal protein or in weaning diets for this species are suggested. Finally, the results obtained in COM-fed fish seem to reflect that specific formulas for this species have not been fully tailored yet. 
Acknowledgements The experimental diets were made in the facilities provided by $\mathrm{CEIA}_{3}$ and CEIMAR (Service of Experimental Diets; http://www.ual.es/stecnicos_spe). The authors acknowledge Fundación Cajamar (Almería, Spain) for kindly providing the microalgae used in this work.

Funding information This study was part of the research projects ECOAQUA, AGR5334, and SABANA (grant \# 727874) from the European Union's Horizon 2020 Research and Innovation program.

\section{References}

Alarcón FJ, Díaz M, Moyano FJ, Abellán E (1998) Characterization and functional properties of digestive proteases in two sparids; gilthead sea bream (Sparus aurata) and common dentex (Dentex dentex). Fish Physiol Biochem 19(3):257-267. https://doi.org/10.1023/A:1007717708491

Andersen NG, Alsted NS (1993) Growth and body composition of turbot (Scopthalmus maximus L.) in relation to different lipid/ protein ratios in the diet. In: Kaushik SJ, Luquet P (eds) Fish nutrition in practice. INRA, Paris, pp 479-491

Association of Analytical Chemists (2000) Official methods of analysis of official analytical chemists international, 17th edn. Association of Analytical Chemists (AOAC), Washington, DC

Barroso FG, Rodiles A, Vizcaíno AJ, Martínez TF, Alarcón FJ (2013) Evaluation of feed attractans in juvenile Senegalese sole, Solea senegalensis. J World Aquacult Soc 44(5):682693. https://doi.org/10.1111/jwas.12068

Bell JG, Henderson RJ, Tocher DR, McGhee F, Dick JR, Porter A, Smullen RP, Sargent JR (2002) Substituting fish oil with crude palm oil in the diet of Atlantic salmon (Salmo salar) affects muscle fatty acid composition and hepatic fatty acid metabolism. J Nutr 132(2):222-230

Bergmeyer HV (1974) Phosphatases methods of enzymatic analysis, vol. 2. Academic Press, New York

Borges P, Oliveira B, Casal S, Dias J, Conceição L, Valente LMP (2009) Dietary lipid level affects growth performance and nutrient utilisation of Senegalese sole (Solea senegalensis) juveniles. Br J Nutr 102(07):1007-1014. https://doi. org/10.1017/S0007114509345262

Bradford M (1976) A rapid and sensitive method for the quantitation of microgramquantities of protein utilizing the principle of protein-dye binding. Anal Biochem 72(1-2):248-254. https://doi.org/10.1016/0003-2697(76)90527-3

Burr GS, Barrows FT, Gaylord G, Wolters WR (2011) Apparent digestibility of macronutrients and phosphorus in plant derived ingredients for Atlantic salmon, Salmo salar and Arctic charr, Salvelinus alpinus. Aquac Nutr 17(5):570-577. https://doi.org/10.1111/j.1365-2095.2011.00855.x

Cabral EM, Bacelar M, Batista S, Castro-Cunha M, Ozório ROA, Valente LMP (2011) Replacement of fishmeal by increasing levels of plant protein blends in diets for Senegalese sole (Solea senegalensis) juveniles. Aquaculture 322-323:74-81. https://doi.org/10.1016/j.aquaculture.2011.09.023

Cabral EM, Fernandes TJR, Campo SD, Castro-Cunha M, Oliveira MBPP, Cunha ML, Valente LMP (2013)
Replacement of fish meal by plant protein ingredientssources up to $75 \%$ induces good growth performance without affecting flesh quality in on growing Senegalese sole. Aquaculture 380-383:130-138. https://doi.org/10.1016/j. aquaculture.2012.12.006

Chen MY, Ye JD, Yang W, Wang K (2013) Growth, feed utilization and blood metabolic responses to different amylaseamylopectin ratio fed diets in tilapia (Oreochromis niloticus). Asian Australas J Anim Sci 26(8):1160-1171. https://doi. org/10.5713/ajas.2013.13022

Christie WW (1982) A simple procedure for rapid transmethylation of glycerolipids and cholesteryl esters. J Lipid Res 23(7):1072-1075

DelMar EG, Largman C, Broderick JW, Geokas MC (1979) A sensitive new substrate for chymotrypsin. Anal Biochem 99(2):316-320. https://doi.org/10.1016/S0003-2697(79 )80013-5

Dias J, Rueda-Jasso R, Panserat S, da Conceiçao LEC, Gomes EF, Dinis MT (2004) Effect of dietary carbohydrate to lipid ratios on growth, lipid deposition and metabolic hepatic enzymes in juvenile Senegalese sole (Solea senegalensis, Kaup). Aquac Res 35(12):1122-1130. https://doi.org/10.1111/j.13652109.2004.01135.x

Dinis MT, Ribeiro L, Soares F, Sarasquete C (1999) A review of the cultivation potential of Solea senegalensis in Spain and in Portugal. Aquaculture 176(1-2):27-38. https://doi. org/10.1016/S0044-8486(99)00047-2

Erlanger B, Kokowsky N, Cohen W (1961) The preparation and properties of two new chromogenic substrates of trypsin. Arch Biochem Biophys 95(2):271-278. https://doi. org/10.1016/0003-9861(61)90145-X

Fernandes TJR, Alves RC, Souza T, Silva JMG, Castro-Cunha M, Valente LMP, Oliveira MBPP (2012) Lipid content and fatty acid profile of Senegalese sole (Solea senegalensis Kaup, 1858) juveniles as affected by feed containing different amounts of plant protein sources. Food Chem 134(3):13371342. https://doi.org/10.1016/j.foodchem.2012.03.026

Fournier V, Huelvan C, Desbruyeres E (2004) Incorporation of a mixture of plant feedstuffs as substitute for fish meal in diets of juvenile turbot (Psetta maxima). Aquaculture 236(1-4): 451-465. https://doi.org/10.1016/j.aquaculture.2004.01.035

Frías-Quintana CA, Álvarez-González CA, Tovar-Ramírez D, Martínez-García R, Camarillo-Coop S, Peña E, Galaviz MA (2017) Use of potato starch in diets of tropical gar (Atractosteus tropicus, Gill 1863) larvae. Aust Fish 2(1):3. https://doi.org/10.3390/fishes2010003

Gatta PP, Parma L, Guarniero I, Mandrioli L, Sirri R, Fontanillas R, Bonaldo A (2011) Growth, feed utilization and liver histology of juvenile common sole (Solea solea L.) fed isoenergetic diets with increasind protein levels. Aquac Res 42(3):313-321. https://doi.org/10.1111/j.13652109.2010.02622.x

Güroy BK, Cirik S, Güroy D, Sanver F, Tekinay AA (2007) Effects of Ulva rigida or Cystoseira barbata meals as a feed additive on growth performance, feed utilization, and body composition in Nile tilapia, Oreochromis niloticus. Turk J Vet Anim Sci 31:91-97

$\mathrm{Hu} \mathrm{CH}, \mathrm{Xu}$ Y, Xia MS, Xiong L, Xu ZR (2007) Effects of $\mathrm{Cu}^{2+}$ exchanged montmorillonite on growth performance, microbial ecology and intestinal morphology of Nile tilapia 
(Oreochromis niloticus). Aquaculture 270:200-206. https://doi.org/10.1016/j.aquaculture.2007.01. 027

Hussein EE-S, Dabrowski K, El-Saidy DMSD, Lee B-J (2013) Enhancing the growth of Nile tilapia larvae/juveniles by replacing plant (gluten) protein with algae protein. Aquac Res 44(6):937-949. https://doi.org/10.1111/j.13652109.2012.03100.x

Imsland AK, Foss A, Conceiçao LEC, Dinis MT, Delbare D, Schram E, Kamstra A, Rema P, White P (2003) A review of the culture potential of Solea solea and S. senegalensis. Rev Fish Biol Fish 13(4):379-407. https://doi.org/10.1007 /s11160-004-1632-6

Kiron V, Sorensen M, Huntley M, Vasanth GK, Gong Y, Dahle D, Palihawadana AM (2016) Deffated biomas of the microalga, Desmodesmus sp., can replace fishmeal in the feeds for Atlantic salmon. Front Mar Sci 3:67. https://doi. org/10.3389/fmars.2016.00067

Kumar V, Sahu NP, Kumar S, Gupta SK (2008) Gelatinized to non-gelatinized starch ratio in the diet of Labeo rohita: effect on digestive and metabolic response and on growth. J Anim Physiol Anim Nutr 92(4):492-501. https://doi.org/10.1111 /j.1439-0396.2007.00739.x

Laemmli UK (1970) Cleavage of structural proteins during the assembly of the head of bacteriophage T4. Nature 227(5259): 680-685. https://doi.org/10.1038/227680a0

Lepage G, Roy CC (1984) Improved recovery of fatty acid through direct transesterification without prior extraction or purification. J Lipid Res 25(12):1391-1396

Lin S, Luo L (2011) Effects of different levels of soybean meal inclusion in replacement for fishmeal on growth, digestive enzymes and transaminase activities in practical diets for juvenile tilapia, Oreochromis niloticus $\times$ O. aureus. Anim Feed Sci Technol 168(1-2):80-87. https://doi.org/10.1016/j. anifeedsci.2011.03.012

Liu XH, Ye CX, Ye JD, Shen BD, Wang CY, Wang AL (2014) Effects of dietary amylose/amylopectin ratio on growth performance, feed utilization, digestive enzymes, and postprandial metabolic responses in juvenile obscure puffer Takifugu obscurus. Fish Physiol Biochem 40(5):1423-1436. https://doi.org/10.1007/s10695-014-9937-4

Lupatsch I (2009) Quantifying nutritional requirements in aquaculture - the factorial approach. In: Burnell G, Allan G (eds) New Technologies in Aquaculture: improving production efficiency, quality and environmental management. Woodhead Publishing, Cambridge, pp 417-439

Martins D, Valente LMP, Lall SP (2007) Effects of dietary lipid level on growth and lipid utilization by juvenile Atlantic halibut (H. hippoglossus L.) Aquaculture 263(1-4):150158. https://doi.org/10.1016/j.aquaculture.2006.10.017

Merrifield DL, Dimitroglou A, Bradley G, Baker RTM, Davies SJ (2009) Soybean meal alters autochthonous microbial populations, microvilli morphology and compromises intestinal enterocyte integrity of rainbow trout, Oncorhynchus mykiss (Walbaum). J Fish Dis 32(9):755-766. https://doi. org/10.1111/j.1365-2761.2009.01052.x

Morais S, Cahu C, Zambonino-Infante JL, Robin J, Ronnestad I, Dinis MT, Conceicao LEC (2004) Dietary TAG source and level affect performance and lipase expression in larval sea bass (Dicentrarchus labrax). Lipids 39(5):449-458. https://doi.org/10.1007/s11745-004-1250-2
Moreira N, Soares S, Valente LMP, Castro-Cunha M, Cunha LM, Guedes de Pinho P (2014) Effect of two experimental diets (protein and lipid vegetable oil blends) on the volatile profile of Senegalese sole (Solea senegalensis Kaup, 1858) muscle. Food Chem 153:327-333. https://doi.org/10.1016/j. foodchem.2013.12.071

Murray HM, Lall SP, Rajaselvam R, Lee AB, Blanchard B, Flight RM, Colombo S, Mohindra V, Douglas SE (2010) A nutrigenomic analysis of intestinal response to partial soybean meal replacement in diets for juvenile Atlantic halibut, Hippoglossus hippoglossus, L. Aquaculture 298(3-4):282293. https://doi.org/10.1016/j.aquaculture.2009.11.001

Olsen RL, Hasan RM (2012) A limited supply of fish meal: impact on future increases in global aquaculture production. Trends Food Sci Technol 27(2):120-128. https://doi.org/10.1016/j. tifs.2012.06.003

Olsen RE, Myklebust R, Ringø E, Mayhew TM (2000) The influences of dietary linseed oil and saturated fatty acids on caecal enterocytes in Arctic charr (Salvelinus alpinus L.): a quantitative ultrastructural study. Fish Physiol Biochem 22(3):207-216. https://doi.org/10.1023/A:1007879127182

Pereira TG, Oliva-Teles A (2003) Evaluation of corn gluten meal as a protein source in diets for gilthead sea bream (Sparus aurata L.) juveniles. Aquac Res 34:1111-1117

Pfleiderer G (1970) Particle-bound aminopeptidase from pig kidney. Methods Enzymol 19:514-521. https://doi.org/10.1016 /0076-6879(70)19038-0

Pham MA, Lee KJ, Lim SJ, Park KH (2007) Evaluation of cottonseed and soybean meal as partial replacement for fishmeal in diets for juvenile Japanese flounder, Paralichthys olivaceus. Fish Sci 73(4):760-769. https://doi. org/10.1111/j.1444-2906.2007.01394.x

Regost C, Arzel J, Cardinal M, Robin J, Laroche M, Kaushik SJ (2001) Dietary lipid level, hepatic lipogenesis and flesh quality in turbot (Psetta maxima). Aquaculture 193(3-4):291309. https://doi.org/10.1016/S0044-8486(00)00493-2

Reitan KI, Eriksen T, Berge GM, Ruyter B, Sørensen M, Galloway TF, Kjørsvik E (2013) Nutrient digestibility and effect on gut morphology of diets with increasing content of dried microalgae Phaeodactylum tricornutum in Atlantic cod and Atlantic salmon. Lecture presented at the 3rd Danish Macro Algae Conference, Grenaa, Denmark, 9th-10th October 2013 (http://www.algecenterdanmark.dk/conferences/)

Rema P, Conceiçao LEC, Evers F, Castro-Cunha M, Dinis MT, Dias J (2008) Optimal dietary protein levels in juvenile Senegalese sole (Solea senegalensis). Aquac Nutr 14(3): 263-269. https://doi.org/10.1111/j.1365-2095.2007.00527.x

Rodiles A, Herrera M, Hachero-Cruzado I, Ruíz-Járabo I, Mancera JM, Cordero ML, Lall SP, Alarcón FJ (2015) Tissue composition, blood biochemistry and histology of digestive organs in Senegalese sole (Solea senegalensis) juveniles fed diets containing different plant protein ingredients. Aquac Nutr 21(6):767-779. https://doi.org/10.1111 /anu.12207

Rodríguez-Ruiz J, Belarbi EH, García JL, López D (1998) Rapid simultaneous lipid extraction and transesterification for fatty acid analyses. Biotechnol Tech 12(9):689-691. https://doi. org/10.1023/A:1008812904017

Rubio VC, Navarro DB, Madrid JA, Sánchez-Vázquez FJ (2009) Macronutrient self-selection in Solea senegalensis fed macronutrient diets and challenged with protein dilutions. 
Aquaculture 291(1-2):95-100. https://doi.org/10.1016/j. aquaculture.2009.02.040

Sáenz de Rodrigáñez MA, Díaz-Rosales P, Chabrillón M, Smidt H, Arijo S, León- Rubio JM, Alarcón FJ, Balebona MC, Moriñigo MA, Cara JB, Moyano FJ (2009) Effect of dietary administration of probiotics on growth and intestine functionally of juvenile Senegalese sole (Solea senegalensis, Kaup 1858). Aquac Nutr 15(2):177-185. https://doi. org/10.1111/j.1365-2095.2008.00581.x

Santigosa E, Sánchez J, Médale F, Kaushik S, Pérez-Sánchez J, Gallardo MA (2008) Modifications of digestive enzymes in trout (Oncorhynchus mykiss) and sea bream (Sparus aurata) in response to dietary fishmeal replacement by plant protein sources. Aquaculture 282(1-4):68-74. https://doi. org/10.1016/j.aquaculture.2008.06.007

Silva FCP, Nicoli JR, Zambonino-Infante JL, Le Gall M, Kaushik S, Gatesoupe FJ (2010) Influence of partial substitution of dietary fishmeal on the activity of digestive enzymes in the intestinal brush border membrane of gilthead sea bream, Sparus aurata and goldfish, Carassius auratus. Aquaculture 306(1-4):233-237. https://doi.org/10.1016/j. aquaculture.2010.05.018

Sorensen M, Berge GM, Reitan KI, Ruyter R (2016) Microalgae Phaeodactylum tircornutun in feed for Atlantic salmon (Salmo salar)-effect on nutrient digestibility, growth and utilization of feed. Aquaculture 460:116-123. https://doi. org/10.1016/j.aquaculture.2016.04.010

Spolaore P, Joannis-Cassan C, Duran E, Isambert A (2006) Commercial applications of microalgae. Review. J Biosci Bioeng 101(2):87-96. https://doi.org/10.1263/jbb.101.87

Teimouri M, Amirkolaie AK, Yeganeh S (2013) The effects of Spirulina platensis meal as a feed supplement on growth performance and pigmentation of rainbow trout (Oncorhynchus mykiss). Aquaculture 396-399:14-19. https://doi.org/10.1016/j.aquaculture.2013.02.009

Tibaldi E, Chini Zittelli G, Parisi G, Bruno M, Giorgi G, Tulli F, Venturini S, Tredici MR, Poli BM (2015) Growth performance and quality traits of European sea bass (D. labrax) fed diets including increasing levels of freeze-dried Isochrysis sp. (T-ISO) biomass as a source of protein and n-3 long chain PUFA in partial substitution of fish derivatives. Aquaculture 440:60-68. https://doi. org/10.1016/j. aquaculture.2015.02.002

Tocher DR (2003) Metabolism and functions of lipids and fatty acids in teleost fish. Rev Fish Sci 11(2):107-184. https:/doi. org $/ 10.1080 / 713610925$

Torzillo G, Pushparaj B, Bocci F, Balloni W, Materassi R, Florenzano G (1986) Production of Spirulina biomass in closed photobioreactors. Biomass 11(1):61-74. https://doi. org/10.1016/0144-4565(86)90021-1

Valente LMP, Linares F, Villanueva JLR, Silva JMG, Espe M, Escórcio C, Pires MA, Saavedra MJ, Borges P, Medale F, Alvarez-Blázquez B, Peleteiro JB (2011) Dietary protein source or energy levels have no major impact on growth performance, nutrient utilisation or flesh fatty acids composition of market-sized Senegalese sole. Aquaculture 318(12): $128-137$. https://doi.org/10.1016/j . aquaculture.2011.05.026

Vizcaíno AJ, López G, Sáez MI, Jiménez JA, Barros A, Hidalgo L, Camacho-Rodríguez J, Martínez TF, Cerón-García MC, Alarcón FJ (2014) Effects of the microalga Scenedesmus almeriensis as fishmeal alternative in diets for gilthead sea bream, Sparus aurata, juveniles. Aquaculture 431:34-43. https://doi.org/10.1016/j.aquaculture.2014.05.010

Vizcaíno AJ, Saéz MI, López G, Arizcun M, Abellán E, Martínez TF, Cerón-García MC, Alarcón FJ (2016) Tetraselmis suecia and Tisochrysis lutea meal as dietary ingredients for gilthead sea bream (Sparus aurata L.) fry. J Appl Phycol 28(5):28432855. https://doi.org/10.1007/s10811-016-0845-0

Walker AB, Berlinsky DL (2011) Effects of partial replacement of fishmeal protein by microalgae on growth, feed intake, and body composition of Atlantic cod. N Am J Aquac 73:76-83. https://doi.org/10.1080/15222055.2010.549030 